\title{
QUANTITATIVE OBSERVATIONS OF FEVER AND ITS TREATMENT BEFORE THE ADVENT OF SHORT CLINICAL THERMOMETERS
}

\author{
by
}

\section{J. WORTH ESTES *}

\section{INTRODUCTION}

The diagnosis of fever syndromes had rested on both objective and subjective feelings of warmth since antiquity, but by the seventeenth century a fast pulse had become the single most common criterion for diagnosing any fever. For instance, in 1692, Thomas Willis was quite explicit about the importance of this diagnostic clue: "First, we consult the Pulse as a Thermometer constituted by Nature for measuring the heat kindled in a Fever." "Three years later Friedrich Hoffmann explained the febrile rapid pulse as a reflex that occurs when blood vessels become obstructed, and agreed that "a rapid or frequent pulse is present in all fevers". ${ }^{2}$ Hermann Boerhaave made it an article of faith that a rapid pulse is pathognomonic of fever. ${ }^{3} \mathrm{He}$, Hoffmann, and, later, William Cullen, who tried to shift the pathophysiological focus to the nervous system, ${ }^{4}$ proposed classifications of fever based on their own respective theories of its origin. ${ }^{5}$ However, their diverse hypotheses did not much affect the bedside reasoning that led clinicians to diagnose fevers in most patients with rapid pulses, even in some who did not feel ill. Moreover, fever could be diagnosed in patients with normal or slow pulse rates, if their other symptoms warranted it.

* J. Worth Estes, MD, Professor of Pharmacology (History of Pharmacology), Boston University School of Medicine, 80 East Concord Street, Boston, MA 02118-2394, USA.

An early version of this paper was presented at the annual meeting of the American Association for the History of Medicine, New Orleans, Louisiana, 4-7 May 1988. I am most grateful to John Burnett, Desirée Carlson, Philip Cash, Louis Lasagna, Adam G. N. Moore, Robin Price, Guenter B. Risse, Richard J. Wolfe, and Gretchen Worden for helpful contributions to this study.

${ }^{1}$ Dr [Thomas] Willis, The London practice of physick, London, T. Basset, T. Dring, C. Harper, \& W. Crook, 1692, p. 575.

${ }^{2}$ Friedrich Hoffmann, Fundamenta medicinae (1695), transl. Lester S. King, London, Macdonald, 1971. pp. 41,48 . p. 125

${ }^{3}$ Lester S. King, The medical world of the eighteenth century, Huntington, N.Y., Robert E. Krieger, 1971,

${ }^{4}$ William Cullen, First lines of the practice of physic, new ed., 4 vols., Edinburgh, E. Elliot, and C. Elliot \& T. Kay, 1789, vol. 1, pp. 102-3.

${ }^{5}$ W. F. Bynum, 'Cullen and the study of fevers in Britain, 1760-1820', in W. F. Bynum and V. Nutton (eds.), Theories of fever from antiquity to the Enlightenment, London, Wellcome Institute for the History of Medicine, 1981, pp. 135-47; Dale C. Smith, 'Medical science, medical practice, and the emerging concept of typhus in mid-eighteenth-century Britain', ibid., pp. 121-34; idem. 'Quinine and fever: the development of the effective dosage', J. Hist. Med., 1976, 31: 343-67. For a non-infectious disease, dropsy, that was considered a fever because of its characteristic fast pulse, see J. Worth Estes, Hall Jackson and the purple foxglove, Hanover, N. H., University Press of New England, 1979, pp. 150-1, 160. 


\section{J. Worth Estes}

Several kinds of thermometers had become available by the late eighteenth century. The first, which used air as the expandable medium, was probably invented by Galileo about 1595, although Sanctorius appears to have been the first to describe one in print, in works he published in 1604-1618. Thirty years later, Duke Ferdinand II of Tuscany substituted alcohol for air and sealed the previously open end. Sir Isaac Newton used a thermometer filled with linseed oil to measure human body temperature around 1700 . Fourteen years afterward Daniel Fahrenheit introduced the mercury-filled thermometer with a scale he had developed by working up from a fixed point of $96^{\circ}$ for human body heat to $212^{\circ}$, because it was the boiling point of water, and down to $32^{\circ}$, because it was the temperature of a thick mixture of ice and water. ${ }^{6}$

By 1740, several investigators, including Newton, had tried to standardize thermometric instruments. Of the four types available by then-using air, linseed oil, alcohol, or mercury as indicators-Fahrenheit's was the most popular, probably because it gave the most consistent results, although it was employed far more often for measuring ambient air temperature than body temperature. ${ }^{7}$ By the end of the eighteenth century, examples of each type had been imported from England for use in laboratories at Harvard and Yale colleges. ${ }^{8}$ Contemporary physicians, however, used Fahrenheit thermometers chiefly for measuring meteorological changes and their influence on the incidence of disease. ${ }^{9}$

The astronomers Kepler and Galileo had used pendulums and balance clocks to estimate the pulse rate. Physicians could finally begin to measure it accurately when watches with second hands were introduced in the 1690 s, especially those designed with doctors' needs in mind. ${ }^{10}$ In 1707 Sir John Floyer published his observations of patients with different diagnoses, using a watch that ran for 60 seconds. His work showed that pulse-counting was practical and reproducible. In the preface to The physician's pulse-watch, he outlined why it was necessary to measure short time intervals accurately: "[O]ur Life consists in the Circulation of blood, and that running too fast or slow, produces most of our Diseases. The Physician's Business is to regulate the Circulation, and to keep it in a moderate degree." After explaining that it is not really necessary for a physician to know the theoretical mechanisms underlying the

\footnotetext{
${ }^{6} \mathrm{~S}$. Weir Mitchell, The early history of instrumental precision in medicine, New Haven, Tuttle, Morehouse \& Taylor, 1892, pp. 10-16, 30-42; G. Sims Woodhead and P. C. Varrier-Jones, 'Clinical thermometry: continuous and quasi-continuous temperature records in man and animals in health and disease. Part $I$. The clinical thermometer', Lancet, 1916, i: 173-80. Galileo's word "thermoscope" was replaced by "thermometer" by Jean Leurechon, in his Recréation mathématique of 1624, according to Lynn Thorndike, A history of magic and experimental science, 8 vols., New York, Columbia University Press, 1923-58, vol. 7, 1958 , p. 593.

${ }^{7}$ George Martine, Essays, medical and philosophical, London, A. Millar, 1740, pp. 177-230; 'Pneumatics' entry in Encyclopaedia Britannica, 3 vols., Edinburgh, A. Bell \& C. Macfarquhar, 1771, vol. 3, pp. 486-7.

${ }^{8}$ I. Bernard Cohen, Some early tools of American science, Cambridge, Mass., Harvard University Press, 1950, pp. 49, 75, 90, 120, 144, 150; Leonard Tucker, 'President Thomas Clap of Yale College: another "founding father" of American science', in Brooke Hindle (ed.), Early American science, New York, Science History Publications, 1976, pp. 97-119, esp. pp.109-10.

${ }^{9}$ Estes, op. cit., note 5 above, pp. 119-20; Everett Mendelsohn, 'John Lining and his contributions to early American science', Isis, 1960, 51: 278-92.

${ }^{10}$ Mitchell, op. cit., note 6 above, pp. 17-22, 29-30, 32; David S. Landes, Revolution in time, Cambridge, Mass., Harvard University Press, 1983, pp. 129-30.
} 


\section{Quantitative observations of fever}

production of body heat, Floyer went on to assert that, "Tis enough that I know by a hot Regimen and hot Tastes I can raise deficient Pulses, and by a cold Regimen and Medicines of a cool Taste, I can depress and sink the number of exceeding Pulses. By this method all fine Hypotheses will be excluded from Practice." 11 After summarizing his observations of pulse rates in various conditions of health and disease, and taking the ambient temperature into account, Floyer concluded that "if I can measure the frequency by counting the number of Pulses in one minute, I can thereby measure the Heat of the Blood." 12

Thus by 1715 physicians had available to them two instruments that might have provided them with previously unparallelled opportunities for studying, with some precision, the natural history of fevers as well as responses to their remedies. But clear differentiations of many fever syndromes did not appear until well into the nineteenth century. We must consider, then, the reasons for the long latent period between the development of the pulse watch and the thermometer, on the one hand, and the effective classification of fever syndromes by their most readily quantifiable property, on the other.

The reasons cannot lie in any widespread failure to appreciate the usefulness of a quantitative approach to medicine. Harvey had depended on it to help explain his circulation theory when he computed what is now called stroke volume and, by extension, cardiac output per hour. ${ }^{13}$ Not long afterward, the members of the Royal Society unequivocally stated that they wished to bring "all things as near the Mathematical plainess, as they can". ${ }^{14}$ The Society's members exploited mathematical approaches in almost the entire spectrum of their researches-but not those on medical, physiological, or anatomical topics. ${ }^{15}$

Even non-scientists thought that applied mathematics, especially simple enumeration, could assist study of the world around them, including medicine. Following a clue in a paper by Benjamin Franklin, Thomas Malthus made widely-read forecasts based on population counts, ${ }^{16}$ and Adam Smith measured economic wealth. As Samuel Johnson told James Boswell in 1783, counting "brings everything to a certainty, which before floated in the mind indefinitely". "In 1807, Thomas Jefferson wrote to Caspar Wistar, with a touch of sarcasm, that "I have lived myself to see the disciples of Hoffman [sic], Boerhaave, Stahl, Cullen, Brown, succeed one another like the shifting figures of a magic lantern ... The patient, treated on the fashionable theory, sometimes gets well in spite of the medicine. The medicine therefore restored

\footnotetext{
${ }^{11}$ Sir John Floyer, The physician's pulse-watch, London, Sam. Smith \& Benj. Walford, 1707, pp. i, iv.

12 Ibid., p. 78.

${ }^{13}$ William Harvey, Exercitatio anatomica de motu cordis et sanguinis in animalibus, transl. Chauncey D. Leake, Springfield, Ill., Charles C. Thomas, 1928, pp. 73-80. Leake thought that this was the first use of the quantitative method in physiology (p. 75).

${ }_{14}^{14}$ Robert K. Merton, Science, technology and society in seventeenth-century England, 1938, repr. ed. New York, Harper \& Row, 1970, pp. 20-1.

${ }_{15}$ As can be seen in ibid., pp. 239-61.

16 J. Worth Estes, 'Population growth tables for the United States since colonial times', J. Am. Stud., 1987, 21: 255-63.

17 James Boswell, The life of Samuel Johnson, L.L.D., 1791, repr. ed. New York, Modern Library, n.d., p. 1042; although the context of Johnson's comment was not medical, it reflects a typical Enlightenment opinion.
} 


\section{J. Worth Estes}

him." 18 Thus it is no surprise that, when outlining an educational programme three years later, Jefferson suggested that the theory of medicine should be taught within the department of mathematics he had proposed, although the practice of medicine was to be taught in a separate professional school. ${ }^{19}$ Occasionally a physician might recognize, as Elisha North of New York did in 1811, that both "An increase in the temperature of the body" and "An increased frequency of the pulse" contributed to the definition of fever, but he did not try to relate them in any specific instances. ${ }^{20}$

Accurate measures of pulse and body heat remained absent from the definitions of individual diseases, although in practice "inflammatory fevers" or "synochae" were characterized by pulse rates that were even faster than the moderately elevated pulses that were characteristic of "low nervous" or "typhus" fevers. ${ }^{21}$ Had both been measured simultaneously in patients with, for instance, dropsy or consumption, it might have been recognized long before the late nineteenth century that dropsy was not a fever, and that consumption did not share the pathophysiological mechanisms also thought to be present in dropsy. ${ }^{22}$

Only a small handful of explicitly numerical data pertaining to fever or its treatment were collected over the 160 years after pulse-watches and Fahrenheit thermometers appeared. This paper will focus chiefly on the few applications of quantitative methods to the expressly clinical assessment of fever and its remedies made before about 1870 , and suggest why the use of numerical data obtained by instrumentation, although they were becoming increasingly important in experimental chemistry and physics, was not expanded into the study of a disease - fever-that was clearly analogous to common chemical and physical phenomena that were routinely studied by mensuration.

\section{THE CLINICAL PROBLEM IN THE EIGHTEENTH CENTURY}

A typical eighteenth-century clinical description of the illnesses collectively categorized as fevers was given in the 1771 first edition of the Encyclopaedia Britannica. It reflected current concepts of fever-mostly Cullen's (although it discounted some of his ideas as "defective")-as a "spasmodic affection" of the nervous and vascular systems. Therefore, said the anonymous author, its symptoms include pain in the loins, cold and pale extremities, shivering, cardiac palpitations, a small weak pulse, dyspnoea, violent headache, restlessness, constipation, and reduced output of urine and sweat. "Whatever has a power to irritate . . the nervous and vascular system to spasms", he went on, "is most likely to generate a fever." ${ }^{23}$ The Encyclopaedia also described wine, linseed oil, and mercury thermometers, and noted the technical reasons for the range of variations in readings obtained with them. However, the observation

${ }^{18}$ Saul K. Padower (ed.), The complete Jefferson, New York, Tudor, 1943, p. 1062.

${ }^{19}$ Ibid., p. 1066.

${ }^{20}$ Elisha North, $A$ treatise on a malignant epidemic, commonly called spotted fever, New York, T. \& J. Swords, 1811, p. 18.

${ }^{21}$ Mitchell, op. cit., note 6 above, pp. 22-3; Guenter B. Risse, "“Typhus" fever in eighteenth-century hospitals: new approaches to medical treatment', Bull. Hist. Med., 1985, 59: 176-95.

${ }^{22}$ Estes, op. cit., note 5 above, pp. 151-61, 174-5, 177-81, 225-6. Hysteria is an example of a possible further confusion. Even if Cullen did not include the "convulsive distemper" in his class Pyrexiae, it was generally associated with a very high pulse; Guenter B. Risse, "Hysteria at the Edinburgh Infirmary: the construction and treatment of a disease, 1700-1800', Med. Hist., 1988, 32: 1-22.

${ }^{23}$ Britannica, note 7 above, vol.3, pp. 59-61. 


\section{Quantitative observations of fever}

that "the greatest degree of heat in the external parts of the human body is commonly about 96", appeared in the Encyclopaedia article on pneumatics, not in the one on medicine. ${ }^{24}$

Professors of medicine often debated the causes of fever, ${ }^{25}$ but its simple identification and treatment were of far more concern. Both academic and nonacademic practitioners interpreted dropsy, for instance, as a fever because the pulse was characteristically rapid. ${ }^{26}$ In his posthumous Commentaries (1802), William Heberden described fever simply as a "general languidness with a quick pulse", although he was well aware that it could take several different clinical forms. ${ }^{27}$

In 1768 he had listed the pulse rates to be expected as the body ages: first month of life, 108-140 beats per minute; first year, 80-120: second year, 90-108; third through sixth years, 80-108; seventh year, 72 or more; twelfth year, 70 ; and, for adults, $60-80 .^{28}$ Heberden went on to note that the pulse might increase by ten or twelve beats per minute after a full meal. He also cautioned that an infant's pulse might rise to 140 without much hazard, but that a pulse of 120 was a danger signal in adults, although some would recover even if it reached 150 or more. However, other physicians thought recovery after such a high "fever" was very rare. ${ }^{29}$

In 1798 John Millar of London described fever as "an increase of heat, a frequent pulse, and a disturbance of some of the animal functions or natural operations." 30 Therefore, if it was true that "The cause of the febrile motion [of the vessels] is an universal spasm", as the Encyclopaedia Britannica had said, recovery from fever would be signalled by free perspiration, slowing of the pulse, the appearance of sediment in the urine, and gradual return of the body's strength. ${ }^{31}$

The majority of eighteenth-century physicians employed several standard methods to hasten those favourable changes. ${ }^{32}$ Initial therapy was usually antiphlogistic, to calm the hyperactive cardiovascular or nervous systems which had increased the pulse rate. It seems not to have mattered very much to most physicians' therapeutic choices which system was most closely implicated as the root cause of the hyperactivity. Febrile patients (i.e., those with fast pulses) had to avoid activities such as exercise, or

24 Ibid., pp. 486-7.

${ }^{25}$ See, e.g., James Currie, Medical reports on the effects of water, cold and warm, 4th ed., 2 vols., London, T. Cadell \& W. Davies, and Edinburgh, W. Creech, 1805, vol. 1, pp. 226-43; Bynum and Nutton (eds.), op. cit., note 5 above, passim, and Estes, op. cit, note 5 above, pp. 150-1, 160.

${ }^{26}$ Smith, 'Medical science', note 5 above; also see note 22 above.

${ }^{27}$ William Heberden, Commentaries on the history and cure of diseases, London, T. Payne, 1802, pp. $175-6$.

${ }_{28}$ Idem, 'Remarks on the pulse', Med. Trans. Coll. Phys., London, 1772, 2: 18-20; he had read this paper at a meeting of the College on 7 July 1768.

${ }^{29}$ See, e.g., the manuscript notes by a student at the Royal Infirmary, Edinburgh, 'Clinical lectures and cases, 1789-1796, of Dr. James Gregory', MSS B51, National Library of Medicine, Bethesda, MD.; the citation is to Gregory's unpaginated lecture on 'Febras [sic] continua' that follows p. 188 of the clinical cases.

${ }_{30} \mathrm{John}$ Millar, Observations on the prevailing diseases in Great Britain, London, for the author, 1798, p. 377.

${ }^{31}$ Britannica, note 7 above, vol. 3, pp. 60-1.

32 J. Worth Estes, 'Drug usage at the infirmary: the example of Dr. Andrew Duncan, Sr.', appendix D in: Guenter B. Risse, Hospital life in Enlightenment Scotland: care and teaching at the Royal Infirmary of Edinburgh, Cambridge University Press, 1986, pp. 351-84; also see pp. 177-225 in the main text of Risse's book. For the sequencing of drug administrations, see J. Worth Estes, 'Naval medicine in the age of sail: the voyage of the New York, 1802-1803', Bull. Hist. Med., 1982, 56: 238-53. 


\section{J. Worth Estes}

substances such as meat, that would "feed" the fires of the inflammation. They were treated with "sedative" or "depletive" drugs, such as cooling (and often diuretic or diaphoretic) acids and salts, and with measures designed to reduce the tension and tone of the arteries, including bleeding. Among the other evacuant remedies designed to counteract vascular spasms were emetics, to divert the dangerous spasmodic activity to the gastrointestinal arteries from which it could be dissipated most efficiently. Warm water was sometimes used to relax hyperactive superficial vessels.

After a day or two, stimulating measures were employed to increase the action of the heart and arteries in order to speed the removal of whatever pathogenic factors had selectively debilitated the fevered body. Among such tonic methods were cold water and such drugs as Peruvian bark, alcohol, iron salts, and several aromatic spices. Although the apparent efficacy of those remedies might have been explained by a series of experiments performed about 1730, these seem to have been overlooked by most physicians.

\section{STEPHEN HALES'S EXPERIMENTS WITH VASOACTIVE DRUGS USED IN FEVER (1733)}

The Rev. Stephen Hales, who had performed a number of quantitative experiments in chemistry and physics while at Cambridge, is remembered today chiefly for his pioneering observations of blood pressure in horses, published in 1733. He also discovered, using measurements he made in many experiments, that blood pressure is directly related, and that pulse rate is inversely related, to body size, and, following Harvey, that what we now call cardiac output is the product of the pulse rate and the internal volume of the left ventricle. ${ }^{33}$

In addition, Hales studied the effects on arterial diameter of several drugs that had long been used in the treatment of fever, although he did not say whether he chose them specifically for that reason. Instead, he seems to have selected his experimental drugs chiefly because he could predict, perhaps from his medical reading, that they would alter arterial diameter and, therefore, the peripheral vascular resistance he thought determined blood pressure. He must have been somewhat familiar with physicians' ideas about the drugs he tested, such as Hoffmann's description of Peruvian bark as "gently astringent ... it strengthens, and by gentle constriction makes firm the very pores and subcutaneous vessels that are too lax and too disposed to stasis of the humours; and imparts to them new strength and vigour."34

Hales began each of his studies of the effects of contemporary fever remedies on peripheral arterial resistance ${ }^{35}$ by exsanguinating a dog and then slitting the entire length of its small intestine opposite the side penetrated by the mesenteric arteries (that is, along the greater curvature). Next he inserted a copper tube, topped by a funnel, into the descending aorta. The tube was 4.5 feet high, to create a pressure head equal to that created by the heart at systole. In each experiment Hales measured the time required

\footnotetext{
${ }^{33}$ Henry Guerlac, 'Stephen Hales', in Charles Coulston Gillispie (ed.), Dictionary of scientific biography, New York, Charles Scribner's Sons, 1972, vol. 6, pp. 35-48; I. Bernard Cohen, 'Stephen Hales', Scient. American, May 1976, pp. 98-107; also see note 13 above.

34 Hoffmann, op. cit., note 2 above, p. 52.

${ }^{35}$ Stephen Hales, Statical essays: containing haemastaticks; or, an account of some hydraulick and hydrostatical experiments made on the blood and blood-vessels of animals, 2 vols., London, W. Innys, R. Manby, \& T. Woodward, 1733, vol. 2, pp. 48-63, 126-139.
} 


\section{Quantitative observations of fever}

for fluids poured into the funnel to empty from it as they passed out of the cut intestinal wall edges. He used a pendulum with a one-second swing to measure the time for each potful of fluid, containing 18 cubic inches-about $300 \mathrm{ml}$ - to leave the funnel.

Table 1 shows all the data Hales reported for these experiments. In the first, seven pots of the "blood-warm" water he used as an explicit negative control drained from the funnel in 52 to 46 seconds. Brandy required somewhat longer to drain out, 68 to 72 seconds, but Hales was satisfied that the system was still capable of responding because the next control ran out almost as fast as the first had. A single pot of cold water took much longer to be emptied, 134 seconds, so Hales concluded that it had constricted the blood vessels. Conversely, the gradually decreasing emptying times associated with increasing water temperature convinced him that heat dilates the arteries.

Table 1: Results of Stephen Hales's mesenteric artery flow rate experiments in dogs (1733).

\begin{tabular}{|c|c|c|}
\hline $\begin{array}{l}\text { Warm Water, } 7 \text { pots: } \\
\text { Brandy, } 5 \text { pots: } \\
\text { Warm Water, } 1 \text { pot: } \\
\text { Cold Water }\left(46^{\circ} \mathrm{F} .\right), 1 \text { pot } \\
\text { Warm Water, } 1 \text { pot: } \\
\text { Hot Water: } \\
\text { Hotter Water: }\end{array}$ & $\begin{array}{l}\text { no. } 3 \\
\text { no. } 4\end{array}$ & $\begin{array}{l}\text { emptied in } 52 \mathrm{sec} . ; \text { no. } 7 \text {, in } 46 \mathrm{sec} \text {. } \\
\text { emptied in } 68 \mathrm{secs} \text {.; no. } 5 \text {, in } 72 \mathrm{sec} \text {. } \\
\text { emptied in } 54 \mathrm{sec} \text {. } \\
\text { emptied in } 134 \mathrm{sec} \text {. } \\
\text { emptied in } 57 \mathrm{sec} \text {. } \\
\text { emptied in } 27 \mathrm{sec} \text {. } \\
\text { emptied in } 9 \mathrm{sec} \text {. }\end{array}$ \\
\hline $\begin{array}{l}\text { Warm Water: } \\
\text { Peruvian Bark Decoction: } \\
\text { Warm Water, } 12 \text { pots: } \\
\text { Cold Water }\left(46^{\circ} \mathrm{F} .\right) \text { : }\end{array}$ & $\begin{array}{l}\text { no. } 4 \\
\text { no. } 1 \\
\text { no. } 1 \\
\text { no. } 5\end{array}$ & $\begin{array}{l}\text { emptied in } 62 \mathrm{sec} \text {. } \\
\text { emptied in } 72 \mathrm{sec} \text {; no. } 16 \text {, in } 224 \mathrm{sec} \text {. } \\
\text { emptied in } 198 \mathrm{sec} \text {; nos. 8-12, in } 96 \mathrm{sec} \text {. } \\
\text { emptied in } 136 \mathrm{sec} \text {. }\end{array}$ \\
\hline $\begin{array}{l}\text { Warm Water, } 1 \text { pot: } \\
\text { Oak Bark Decoction, } 6 \text { pots: }\end{array}$ & no. 6 & $\begin{array}{l}\text { emptied in } 38 \mathrm{sec} . \\
\text { emptied in } 136 \mathrm{sec} .\end{array}$ \\
\hline $\begin{array}{l}\text { Camomile Flower Decoction: } \\
\text { Scalding Hot Water: } \\
\text { Cinnamon Decoction, Hot: } \\
\text { Warm Milk, } 1 \text { pot: } \\
\text { Camomile Decoction, Scalding, } 1 \text { pot: }\end{array}$ & $\begin{array}{l}\text { no. } 1 \\
\text { no. } 4 \\
\text { no. } 6\end{array}$ & $\begin{array}{l}\text { emptied in } 96 \mathrm{sec} \text {; no. } 11 \text {, in } 138 \mathrm{sec} \text {. } \\
\text { emptied in } 116 \mathrm{sec} \text {. } \\
\text { emptied in } 216 \mathrm{sec} \text {. } \\
\text { emptied in } 15 \mathrm{sec} \text {. } \\
\text { emptied in } 194 \mathrm{sec} \text {. }\end{array}$ \\
\hline $\begin{array}{l}\text { Warm Water: } \\
\text { Piermont Water, Warm: } \\
\text { Pump Water, Warm: }\end{array}$ & $\begin{array}{l}\text { no. } 1 \\
\text { no. } 1 \\
\text { no. } 10\end{array}$ & $\begin{array}{l}\text { emptied in } 68 \mathrm{sec} \text {; nos. } 9-12 \text {, in } 38 \mathrm{sec} \text {. } \\
\text { emptied in } 40 \mathrm{sec} \text {; no. } 17 \text {, in } 76 \mathrm{sec} \text {. } \\
\text { emptied in } 64 \mathrm{sec} \text {. }\end{array}$ \\
\hline
\end{tabular}

Hales next experimented with a strong solution of Peruvian bark. Its apparent efficacy in both intermittent (i.e., malarial) and continuous fevers was at that time associated with its astringent ("styptic") effect on blood vessels, now attributable to the irritant action of its quinine content. He found that the bark progressively prolonged the emptying time, from just ten seconds longer than normal for the first pot of Peruvian bark solution to almost four times longer than normal. Therefore, he concluded, the bark was a vasoconstrictor that increased arterial tone. The emptying time for his warm water control fell gradually as he poured twelve consecutive pots into the same preparation. However, because the emptying time did not quite return to normal, Hales concluded that some of the bark's active principle had remained within 


\section{J. Worth Estes}

the mesenteric arteries, but then, as before, cold water again slowed emptying. In a third dog, with a normal control emptying time, Hales found that a strong decoction of oak bark, another known astringent, gradually decreased the diameter of the mesenteric arteries.

Camomile slowed emptying in a fourth dog-although Hales apologized to his readers for having forgotten to include an initial control fluid for this experiment. Scalding water increased the flow rate slightly, but not as much as hot water had in his first experiments, and cinnamon prolonged the emptying time more than in any other experiment. Warm milk affected the flow rate about as much as hot water had in his first experiments, and a repeat dose of camomile, this time in scalding water, immediately reversed the arterial tone. Hales concluded from these data that camomile and cinnamon could constrict arteries, and, again, that heat dilates them.

In his last experiment, with a fifth dog, he found that the emptying time was nearly doubled by seventeen pots of "Piermont" mineral water, imported from Bad Pyrmont, a spa near Hanover, Germany (although it might have been an artificially manufactured version). ${ }^{36}$ It contained a high concentration of iron (as ferrous sulphate), long considered to be a tonic drug, which led Hales to infer that it, too, had a vasoconstrictor effect. Finally, ten pots of water warmed to the same temperature hastened arterial flow nearly as much as in the very first experiment.

Since Hales had concluded from both other experiments and his reading that blood heat is proportional to the velocity of the blood within the vessels, he could also infer that increased tension on the vascular walls would warm the blood and even "putrify" it at fever heat ${ }^{37}$ As far as he could tell from these five dog experiments, heat dilated arteries, while cold, and the tonic, or strengthening, drugs used to treat weakened febrile patients after the acute stage had passed, such as Peruvian bark, were vasoconstrictors, as were alcohol and iron salts, even when heated.

I have been unable to find any other explicitly experimental data that could have provided the same kinds of "pharmacological" laboratory evidence to support the continued use of these protopharmacological agents in the clinical treatment of patients who had been weakened by fever. Hales's inferences about substances affecting arterial tone were seldom, if ever, cited in medical texts, although they probably were known to British physicians. For instance, John Huxham, who called him "the accurate Dr. Hales", seems to have relied on similar physiological concepts. ${ }^{38}$ Although few later referred to Hales's book, his conclusions were so entirely consistent with the medical theories that prevailed for the next 150 years that it is quite possible his

\footnotetext{
${ }^{36}$ Joseph Priestley, Directions for impregnating water with fixed air, in order to communicate to it the peculiar spirit and virtues of Pyrmont water, London, J. Johnson, 1772, pp. 16-17; J. H. de Magellan, Description of a glass-apparatus ... in a letter to the Rev. Dr. J. Priestley, 3rd ed., London, for the author, 1783 , p. 25 (the latter provides a detailed recipe). Piermont water was known as far away as Boston as the "richest of all the chalybeates", as noted by Benjamin Waterhouse, in an 'Extract from Dr. Waterhouse's MS. Journal to Saratoga in the summer of 1794', Boston Medical Library call no. AMS. H MS c 16.4. It was also judged to be an effective tonic for preventing miscarriage due to laxity of uterine fibres, according to Charles White, Treatise on the management of pregnant and lying-in women (1733), repr. ed. Canton, Mass., Science History Publications, 1987, pp. 30-1.

${ }^{37}$ Hales, op. cit., note 35 above, p. 107.

38 John Huxham, An essay on fevers (3rd ed., 1757), repr. ed. Canton, Mass., Science History Publications, 1988, pp. 2-5, 19-20, 101.
} 


\section{Quantitative observations of fever}

readers merely agreed with him and read on. But his mesenteric artery preparation was a novel —and very quantitative - experimental approach to understanding drug action.

\section{EARLY CLINICAL THERMOMETERS}

Only a few of the earliest medical thermometers have survived. A typical late eighteenth-century example is one made in Edinburgh and now in the Mütter Museum in the College of Physicians of Philadelphia. ${ }^{39}$ About 7.4 inches long, it is slightly bent 1.25 inches from the bulb because it had to remain in the axilla while being read, unlike modern self-registering thermometers in which the mercury level remains stable even after being removed from the mouth. The fact that the bone scale was not permanently fixed to the glass tube, but wired to it, might have posed some difficulty in handling the instrument; however, that problem was probably negligible, since the wiring is still tight. The reverse of the scale interprets the numbers on the obverse; it is labelled "Freezing" at $32^{\circ}$ Fahrenheit, "Temperate" at $48^{\circ}$, "Agreeable" at $64^{\circ}$, "Very Warm" at $80^{\circ}$, and "Blood Heat" at $96^{\circ}$, while "Fever Heat" was anything on up to $112^{\circ}$.

Cullen and his colleagues at the Royal Infirmary of Edinburgh seldom used thermometers because, they said, they could find no consistent association between measured body temperature and their patients' symptoms or their subjective feelings of warmth or cold. ${ }^{40}$ Consequently, most physicians continued to rely on the pulse as the only available numerical index of fever, because it was easy to palpate and could be counted with some accuracy. Cullen was less dependent on the pulse. He taught that the vascular hyperactivity its increase implied was merely a secondary or reflex response to an underlying debility induced by whatever had caused the patient's illness in the first place. ${ }^{41}$ One of his colleagues, James Gregory, did measure his patients' pulses, but he could "not say what degree of Frequency is absolutely fatal". He went on, "In general there is great danger when the pulse has risen to 130", but, he concluded, he knew "of no remedy particularly adapted to the quickness of Pulse". ${ }^{42}$

\section{CLINICAL OBSERVATIONS AND DRUG EVALUATIONS (1789-1795)}

Notes made by medical students on the teaching wards of the Royal Infirmary show how their professors used pulse rates to assess their fever patients' progress from one day to the next, following clinical rationales shared by most physicians trained in the eighteenth century. For example, George Kerr, a 24-year-old servant, was admitted on 9 February 1789 for "pyrexia", with headache, vertigo, nausea, anorexia, polydipsia, cough, and pain in the chest. ${ }^{43}$ Figure 1 (like the next three figures) shows the patient's hospital course in terms of his daily pulse rates and the changes in therapeutic regimen

\footnotetext{
${ }^{39}$ General and clinical thermometer made in Edinburgh by Lovi, catalogue no. 951-Misc. in the Mütter Museum, College of Physicians of Philadelphia, where Gretchen Worden kindly brought it to my attention.

${ }^{40}$ Bynum, op. cit., note 5 above; Risse, op. cit., note 32 above, p. 114.

${ }^{41}$ Cullen, op. cit., note 4 above, vol. 1, pp. 102-3.

42 Gregory, op. cit., note 29 above, 'Febras continua'.

43 Ibid., pp. 109-12. Gregory seems to have made only one thermometric measurement during his three-month rotation on the teaching wards at Edinburgh in the winter of 1789 (ibid., p. 179), but the volumes of the diabetic patient's ingesta and his urine were measured daily (ibid., pp. 173-83), as was routine for such patients (Estes, 'Drug usage', note 32 above, pp. 361-4).
} 
prescribed by Dr Gregory, many of them prompted by the state of the patient's pulse. To stimulate diaphoresis and diuresis, Gregory first prescribed a saline julep made with potassium carbonate (or perhaps the hydroxide), lemon juice, and black currant syrup, and an antimonial compound designed to produce both vomiting and catharsis. Because no stool appeared, an enema was given the next day and on three subsequent occasions; it was so effective the first time that Gregory had to prescribe opium to counteract the drug-induced catharsis.

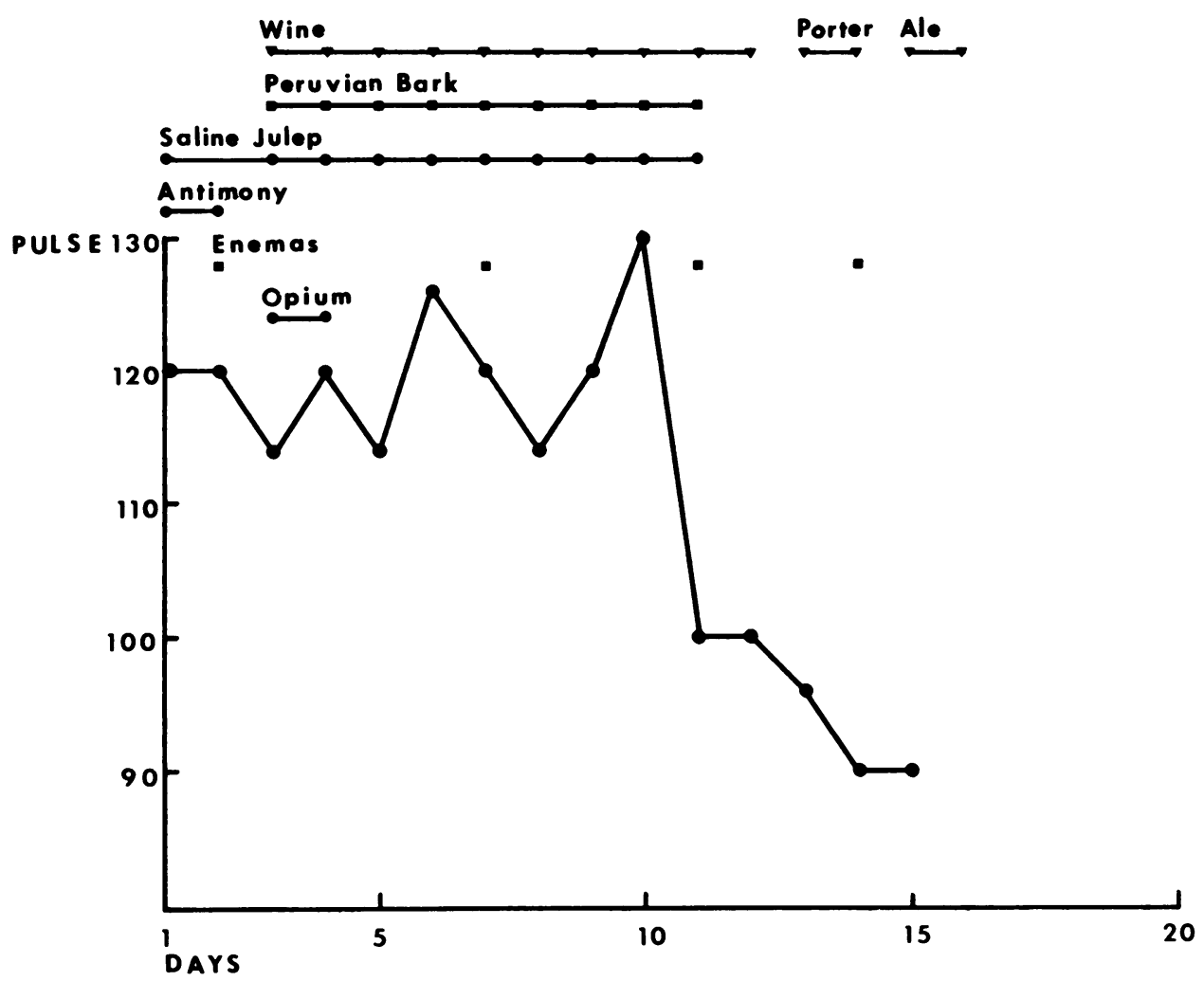

Figure 1. Clinical course of George Kerr at the Royal Infirmary, Edinburgh, as reflected in his pulse rate and treatments in February-March 1789. Compiled from clinical notes cited in note 43.

However, although Kerr's pulse, and by inference his fever, remained high, he became stuporous, so Gregory added wine and Peruvian bark to strengthen his body tones. When Kerr became delirious, the bark was discontinued because it was thought to be too tonic for him. When he began to recover he asked for porter or ale instead of wine. Eventually his pulse began to return toward normal, so Gregory stopped measuring it, and Kerr was discharged as "cured" 25 days after his admission.

The treatment of another of Gregory's typical fever patients was more complex. John Gaudy, aged 17, was admitted on 7 March 1789 with headache and pains in his 


\section{Quantitative observations of fever}

shoulders, sides, loins, and right wrist. ${ }^{44}$ As seen in figure 2, Gregory had him bled four times; his pulse fell to a modest degree after the first two venesections, and the third, prescribed when Gaudy's pulse rose to 120 , was followed by an even more dramatic reduction of his feverish pulse. Leeches were applied to treat pains in his hands, and blisters to counteract pains in his chest.

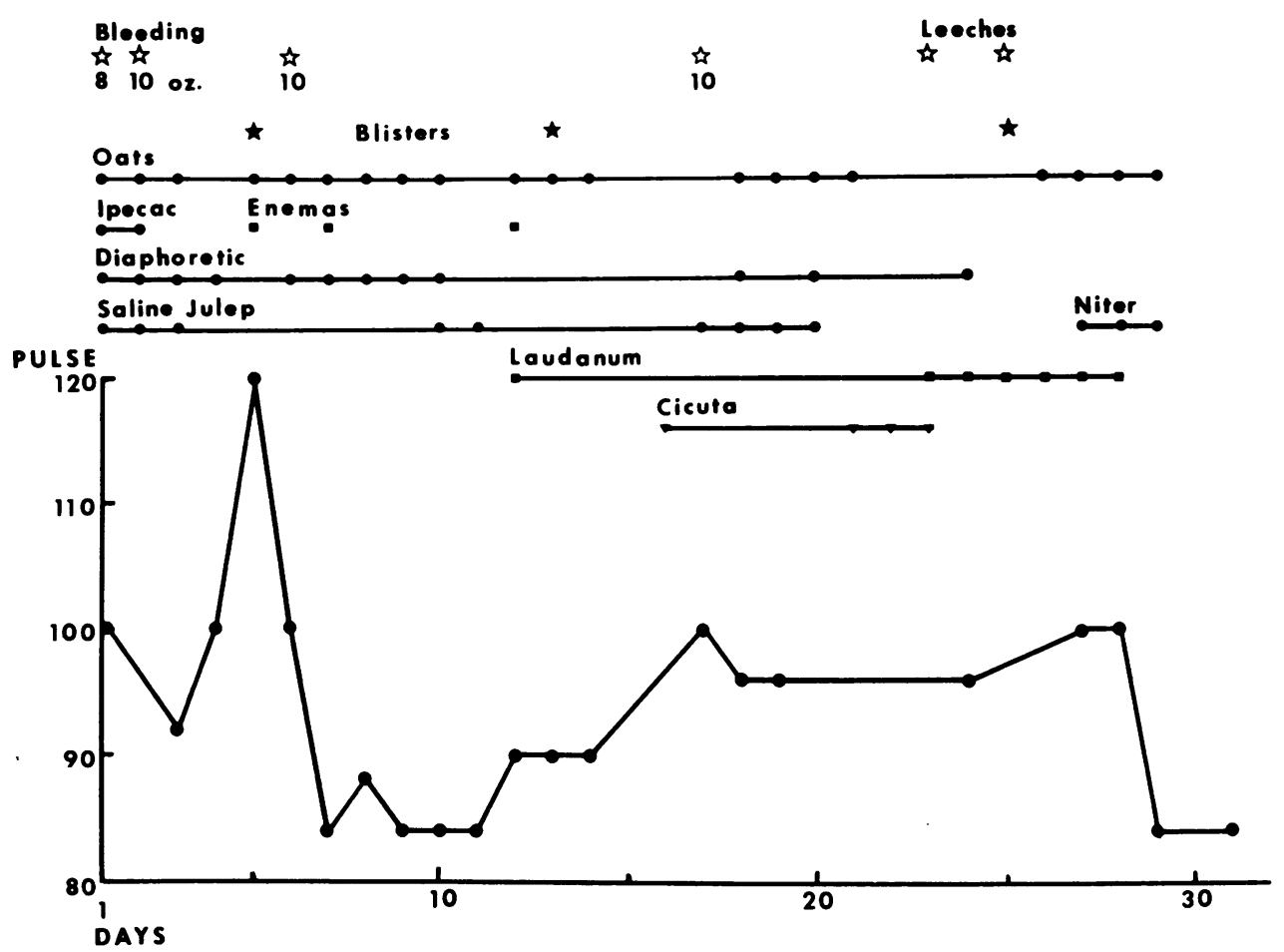

Figure 2. Clinical course of John Gaudy at the Royal Infirmary, Edinburgh, as reflected in his pulse rate and treatments in March-April 1789. Compiled from clinical notes cited in note 44.

To combat this patient's fever, Gregory prescribed ipecac as an appropriate emetic, as well as a diaphoretic (probably an antimonial compound). The saline julep and nitre (potassium nitrate) were given to promote diuresis. Enemas were needed when Gaudy became constipated. Laudanum was given for cough and pain, and cicuta (poison hemlock, Conium maculatum) as a potent tonic when he became debilitated. Oatmeal was prescribed for its nutritive value. Gaudy's pulse finally fell toward normal, and on day 33 the young tailor was discharged as "cured".

Both Gregory and his colleague Andrew Duncan, Sr., noted the pulse rates of their fever patients almost every day - but not those of their afebrile patients-specifically in order to monitor their responses to treatment. ${ }^{45}$ For instance when Janet Ross, 22

44 Gregory, op. cit., note 29 above, pp. 177-83.

${ }^{45}$ Estes, 'Drug usage', note 32 above, passim. 


\section{J. Worth Estes}

years old, was admitted in 1795 with "erysipelas vesiculosum" on her left foot, ${ }^{46}$ Duncan first prescribed conventional remedies for mild febrile disorders (see figure 3): opium for pain, to help her sleep, and to sedate her hyperactive blood vessels; sodium phosphate, as a cooling cathartic; and vegetable acid (probably dilute potassium hydroxide), to stimulate her debilitated gastric muscle fibres. The patient's pulse - that is, her fever-fell within three days.

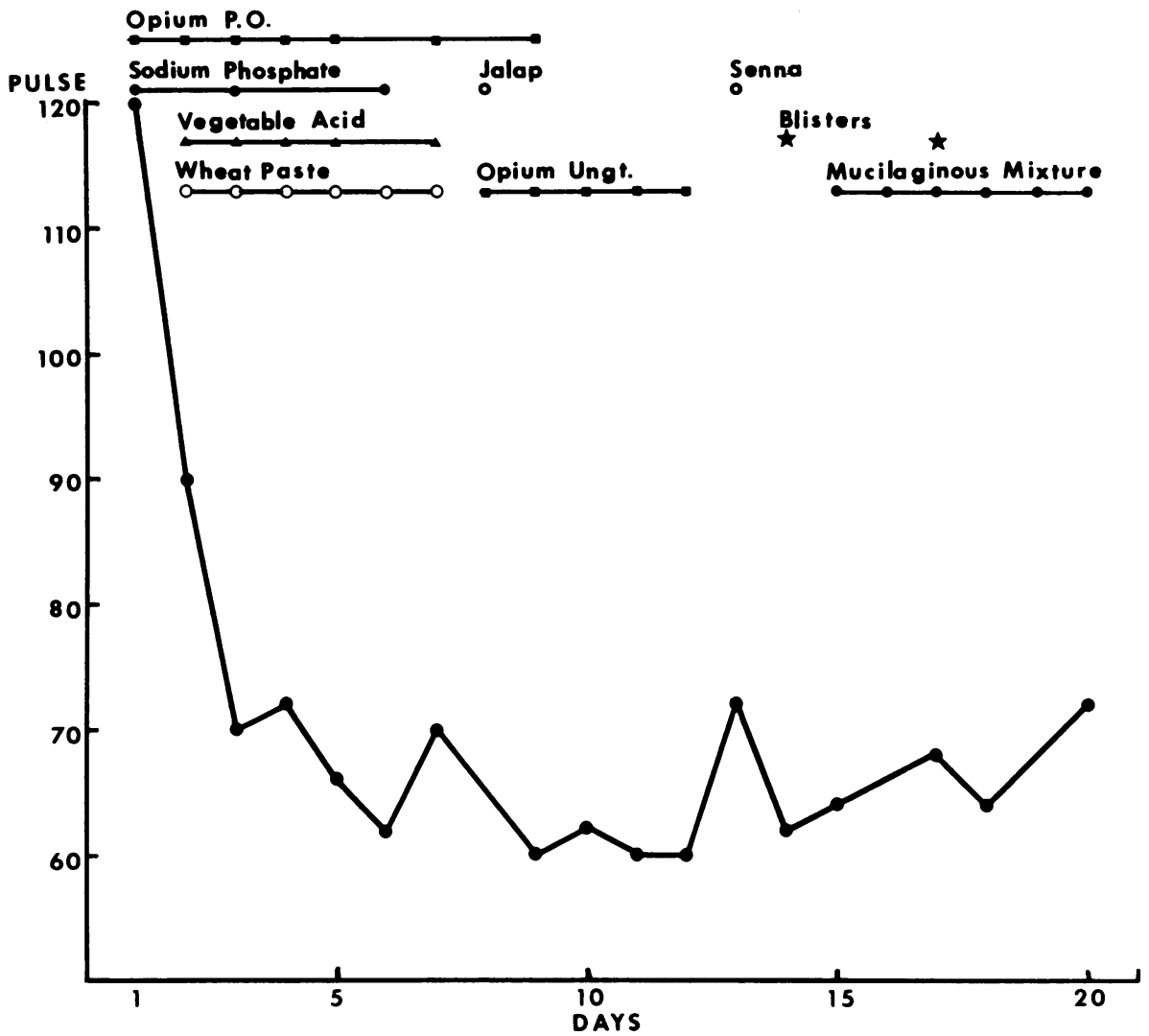

Figure 3. Clinical course of Janet Ross at the Royal Infirmary, Edinburgh, as reflected in her pulse rate and treatments in March 1795. Compiled from clinical notes cited in note 46.

Duncan chose jalap and senna as appropriate cathartics when Ross became constipated. The opium unguent he prescribed for her foot on her eighth hospital day provided local relief, probably because it contained a high concentration of camphor. When Ross developed a cough, Duncan had her drink a "mucilaginous mixture" made of gum arabic in warm water, and he ordered two cantharides blisters, to remove the

${ }^{46}$ Andrew Duncan, Sr., MS 'Clinical reports and commentaries, Feb.-Apr. 1795', n. p., MSS Collection, Royal College of Physicians, Edinburgh. 
"morbid action" from within her chest. In the end, Duncan thought that wheat paste applied directly to her afflicted foot when Ross was admitted was instrumental in permitting her disease to proceed to its "natural recovery". She was discharged after three weeks, "free of all complaints".

From time to time Duncan explicitly experimented with new remedies, especially if standard therapy proved to be ineffective. Figure 4 shows, for example, the case of Daniel MacIntosh, aged 29, who was admitted with consumption and haemoptysis. ${ }^{47}$ Duncan attributed the blood in this patient's sputum to an inflammation of his pulmonary tubercles because his pulse was fast. The doctor first prescribed opium and vitriol (dilute sulphuric acid), and charcoal, a conventional analgesic and tonic regimen. Later he prescribed laudanum when MacIntosh started to cough, and laxatives such as liquorice and castor oil when he became constipated.

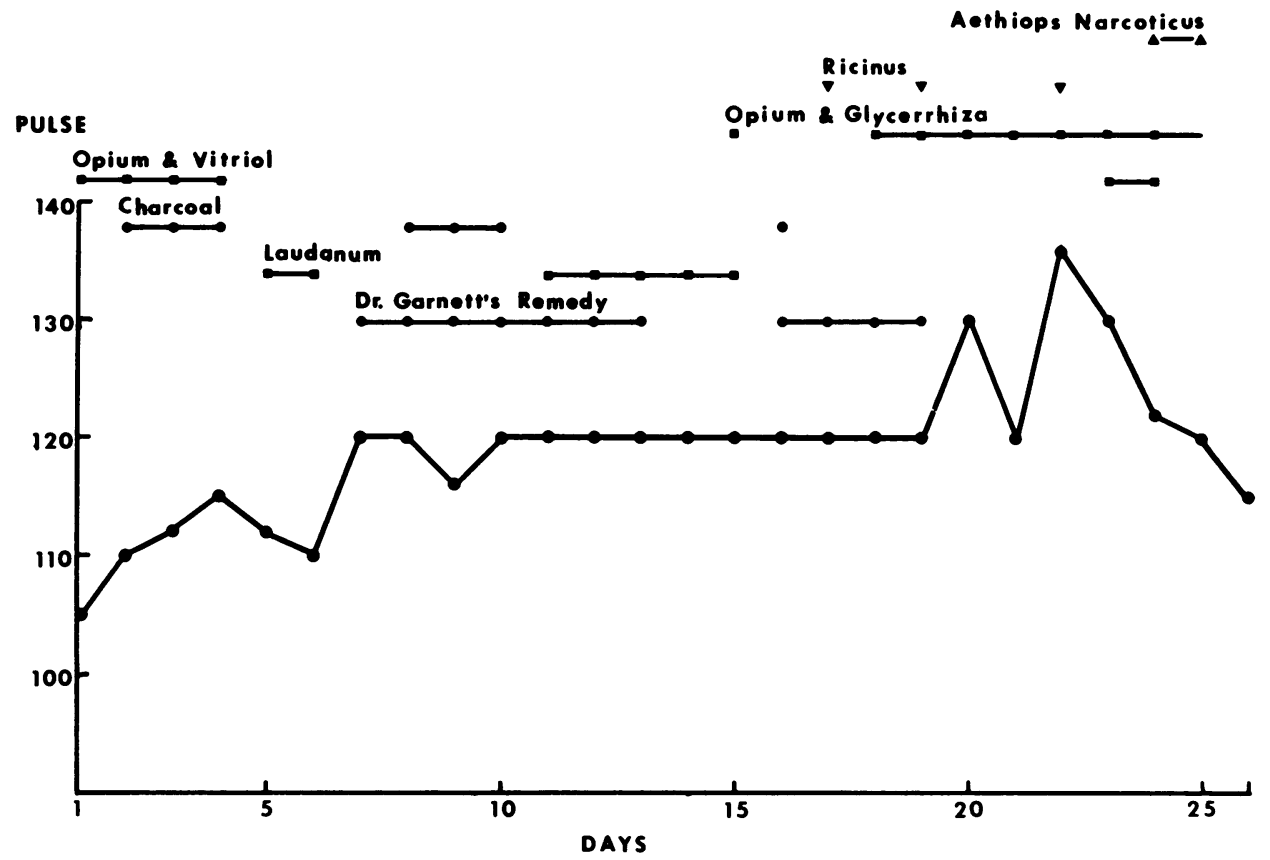

Figure 4. Clinical course of Daniel MacIntosh at the Royal Infirmary, Edinburgh, as reflected in his pulse rate and treatments in March-April 1795. Compiled from clinical notes cited in note 47.

Because the patient's pulse was still fast after a week, Duncan experimented with a mixture recommended by a recent Edinburgh medical graduate, Thomas Garnett of Harrogate. The new drug was made of potassium sulphate and charcoal; perhaps Duncan chose it because its ingredients were chemically similar to the sulphuric acid and charcoal he had given to no avail when MacIntosh was first admitted. According

${ }^{47}$ Ibid. 


\section{J. Worth Estes}

to Duncan, Garnett had based his recipe on Thomas Beddoes's theory that consumption occurred when the blood became "superoxygenated", which led Garnett to reason that, because sulphur and charcoal are easily oxidized, they would "dis-oxygenate" the blood and thereby "remove the morbid state of the inflamed surfaces" of the lung. ${ }^{48}$ However, when MacIntosh's pulse did not fall below 120 , Duncan abandoned his experiment with the purported febrifuge. He tried Garnett's remedy again in his next two consumption cases that winter, but gave it up altogether when it failed to reduce either the pulse rates or the symptoms of those patients.

Just before MacIntosh was discharged Duncan experimented with aethiops narcoticus (prepared by dissolving mercury in nitric acid and then adding potassium sulphate to form a mercuric precipitate; both the sulphide and the sulphate are insoluble in water). Although this drug was "highly extolled and very fashionable in Germany" as a sedative and analgesic that, unlike opium, also moved the bowels, ${ }^{49}$ Duncan found it to be ineffective in this and other patients (even if MacIntosh's pulse rate did fall slightly). In the end, MacIntosh rapidly grew worse, so he was discharged to the country for better air, but he died soon afterward.

Duncan was not, of course, the only experimental clinical investigator at Edinburgh. For instance, his colleague Francis Home published the results of many clinical trials, but his retrospective summary reports ${ }^{50}$ lack the wealth of numerical data found in the day-by-day notes recorded by students when Duncan and Gregory attended on the wards. Still, Edinburgh physicians were typical of their colleagues elsewhere in Europe and America in that they depended on the pulse, not on thermometers, for evaluating their fever patients.

\section{SOME PATHOPHYSIOLOGICAL EXPERIMENTS (1794-1833)}

The Edinburgh physicians' noted London contemporary, John Hunter, seems to have thought that thermometers deserved a more prominent place in everyday medical practice. He noted that the fact that body temperature departs from the "usual" in fever "was first discovered by simple sensation alone, both to the patients themselves, and the practitioner, before the absolute measurement of the degrees of heat by instruments was known; but it was impossible that such knowledge of it could be accurate, for we find by experiment, that the measurement of degrees of heat by sensation is very vague." 51 Hunter used a Fahrenheit thermometer to measure the temperature of artificially-induced inflammations in various parts of the body in

\footnotetext{
${ }^{48}$ Ibid.; for details of the case of Daniel Robertson, in which Duncan explained the rationale behind Garnett's thinking, see Estes, 'Drug usage', note 32 above, pp. 358-9. Duncan probably learned about the potential new remedy in an early edition of Thomas Garnett, $A$ treatise on the mineral waters of Harrogate, 3rd ed., Leeds, Thomas Gill, 1799, pp. 136-7, 143-4, in which Garnett discusses the medicinal virtues of sulphur water, which contained a high concentration of hydrogen sulphide, among the various mineral waters found at Harrogate. He also reviewed the tonic properties of iron on pp. 88-95, although he did not cite Hales's experiments with Piermont water.

${ }^{49}$ Case of Trotter Henderson, in Duncan, op. cit., note 46 above.

${ }^{50}$ Francis Home, Clinical experiments, histories, and dissections, 3rd ed., London, J. Murray, and Edinburgh, William Creech, 1783, pp. 1-51 and passim.

51 John Hunter, A treatise on the blood, inflammation, and gun-shot wounds, London, George Nicol, 1794, p. 292.
} 


\section{Quantitative observations of fever}

several invertebrate species as well as in men, dogs, asses, and frogs (he also noted that the body temperature of the latter parallels that of the ambient air). He concluded that the temperature of local inflammations was greater than that of the uninflamed body, and that such elevated but localized temperatures did not affect sublingual, rectal, or axillary temperatures. 52

Hunter performed several series of experiments in which he measured the pulse, the temperature, or the time required for blood mixed with standard tonic drugs to coagulate. However, those investigations, like many of his others, were so unsystematic that it is difficult to ascertain why he did them, or to understand what conclusions he drew from them, especially because he often neglected to describe either his experimental rationales or the inferences he drew from his data. However, he seems to have agreed with most of his contemporaries about the importance of the activity of the blood vessels, as reflected in the pulse rates of patients with fever and other inflammations. ${ }^{53}$

Hunter regarded the stomach as the principal source of innate body heat, and thought that weakness of the stomach lowered body temperature. ${ }^{54}$ Forty years after Hunter's death, William Beaumont reported thermometric data that would have supported those ideas. The American army surgeon found that exercise increased both the measured temperature of the contents of Alexis St Martin's stomach (by one to one and a half degrees Fahrenheit) and his pulse rate (by ten beats per minute) ${ }^{55}$ Beaumont also found that the amount of food digested in the stomach varied directly with intragastric temperature. ${ }^{56} \mathrm{He}$ concluded that, "In febrile diathesis, very little or no gastric juice is secreted. Hence, the importance of withholding fluid from the stomach in febrile complaints. It can afford no nourishment."57 That is, Beaumont's thermometric measurements supported the ancient admonition to "feed a cold, starve a fever".

PULSE-TEMPERATURE-RESPIRATION CORRELATIONS (1805-1835)

Although virtually all eighteenth-century physicians agreed that the pulse reflected body temperature, they did not use thermometers to collect the numerical data that would have permitted them to assess the magnitude of the relationship or its predictability, much less to confirm that such a relationship even existed. Indeed, as noted earlier, they could find no correlation between measured temperature and the severity of their patients' symptoms.

James Currie of Edinburgh was probably the first investigator to make simultaneous measurements of pulse and temperature, at the very end of the century. He sometimes, but not regularly, measured the body temperature of fever patients before and after treating them with the cold water he was trying to evaluate as a febrifuge. This

52 Ibid., pp. 293-300.

53 Ibid., pp. 97-9, 187, 319-20, 342-3.

54 Ibid., pp. 291, 301.

55 William Beaumont, Experiments and observations on the gastric juice and the physiology of digestion (1833), repr. ed. Boston, XIIIth International Physiological Congress, 1929, pp. 182-247 passim; the raw data are summarized on pp. 273-4.

56 Ibid., pp. 149-53.

57 Ibid., p. 138. 


\section{J. Worth Estes}

therapeutic approach had been suggested to him by Dr William Wright's 1786 account of how he had been cured of a fever with buckets of sea water. ${ }^{58}$ Currie explicitly agreed (in part at least) with Cullen - and probably with Stephen Hales - that fever produced vascular spasms and heat, and he sought to test the hypothesis that cold water would relax the blood vessels ${ }^{59}$ (although, as we have seen, Hale's data suggested that cold water constricts them).

In 1805 Currie noted that "thermometrical observations on the rise and progress of febrile heat are in a great measure new." ${ }^{, 60} \mathrm{He}$ described his thermometer, which he had adapted from one about 6.7 inches long invented by John Hunter, as "a small mercurial thermometer of great sensibility [i.e., sensitivity], with a moveable scale" on the bone collar around it. Currie satisfied himself experimentally that readings obtained by placing the thermometer bulb under the tongue were equivalent to those taken in the axilla. ${ }^{61}$

Figure 5 summarizes the temperature and pulse-rate data he reported. ${ }^{62}$ Although Currie could not have constructed such a graph in 1805, it shows why he could conclude, after considering his entire collection of data, that pulse and temperature are associated clinically. Although the correlation coefficient and the linearity of the data are statistically significant (see table 2 ), the proportional increase in the pulse rate among Currie's patients is small, about three beats per minute per degree rise in temperature.

John Cheyne of Dublin collected data pertaining to pulse, respiratory rate, and thermometrically measured temperature in patients admitted to the Hardwicke Fever Hospital in $1818 .{ }^{63}$ In his published report he presented only frequency distributions for the three clinical signs (for temperature, the mean was $102^{\circ} \mathrm{F}$ and the range $97^{\circ}-109^{\circ}$; the mean pulse rate was $103 \mathrm{bpm}$ and the range was $52-180 \mathrm{bpm}$; and for respiratory rate the mean was $31 / \mathrm{min}$ and the range $20-60 / \mathrm{min}$ ), precluding any attempt to ascertain their statistical correlations with each other. Cheyne reported all three measures simultaneously only for $\mathbf{4 0}$ fever patients whose temperatures exceeded $104^{\circ}$, because he was interested chiefly in assessing the influence of very high temperatures and pulses on physicians' choices of antiphlogistic versus stimulative therapies, and on the likelihood of fatal outcome.

Finally, in 1835 Alfred Donné of Paris, who had studied under Pierre Louis, ${ }^{64}$ published an extensive, systematically collected, series of similar clinical meaurements that he had made specifically in order to study the relationships among pulse, body temperature, and respiratory rate in patients with different febrile conditions, ${ }^{65}$ a task

58 James Currie, Medical reports on the effects of water, cold and warm, Liverpool, J. M'Creery, 1797, pp. $1-5$.

${ }^{59}$ Currie, op. cit., note 25 above, vol. 1, pp. 232, 237-41.

60 Ibid., p. 248.

61 Ibid., p. 35.

62 Ibid., vols. 1 and 2, passim.

$63 \mathrm{~J}$. Cheyne, 'Medical report of the Hardwicke Fever Hospital, for the year ending on the 31 st March, 1818', Dublin Hosp. Repts, 1818, 2: 1-145, esp. pp. 10-11.

${ }^{64}$ Erwin H. Ackerknecht, Medicine at the Paris hospital, 1794-1848, Baltimore, Johns Hopkins Press, 1967 , p. 110.

${ }^{65}$ A. Donné, 'Récherches sur l'état du pouls, de la respiration et de la température du corps dans les maladies, et sur les rapports qui existent entre ces divers phénomènes', Archs génér. Méd., 2nd ser., 1835, 9: 129-57. 


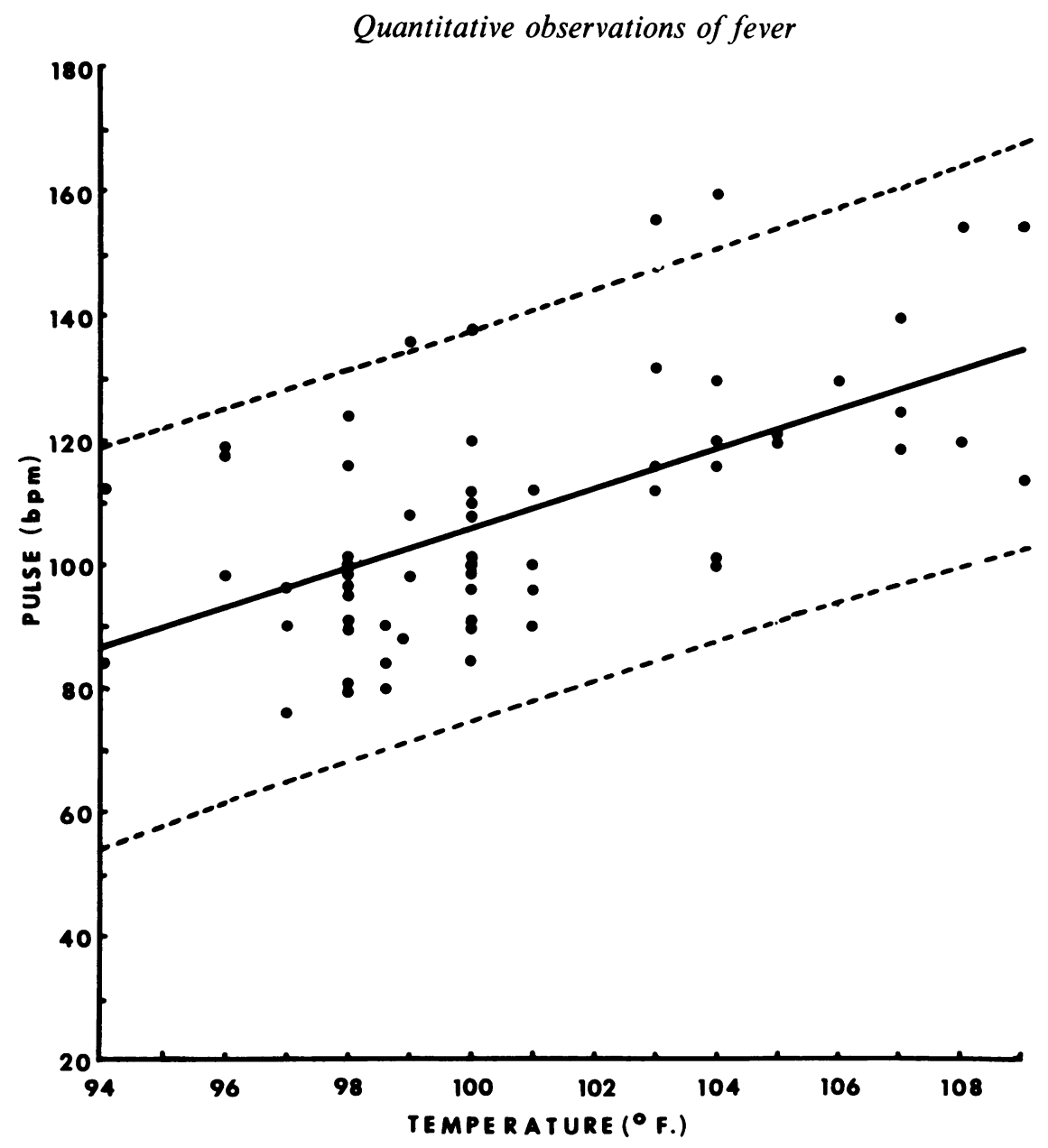

Figure 5. Computed line of best fit $(Y=3.28 X-222 ; N=64)$ and $95 \%$ Confidence Limits (dashed lines) relating pulse rate to thermometrically measured body temperature, from data for 47 patients collected by James Currie in the 1790s. Compiled from source cited in note 62 .

that Louis had been unable to accomplish. ${ }^{66}$ Donné used a thermometer of his own design that he placed in the axilla for ten to fifteen minutes because it required at least five minutes to equilibrate; the upper limit of normal among his patients was $36.9^{\circ} \mathrm{C}$ $\left(98.4^{\circ} \mathrm{F}\right)$. He timed the pulse with the second hand on his pocket watch.

When Donné looked over the data he had collected, in simple tabular form, he could find no consistent ratio of pulse rate to measured temperature, but in the aggregate they confirmed, to his satisfaction, his hypotheses that the two measured variables were associated, and that fever resulted when arterial fibres were constricted by being irritated. The pulse data for all his patients, regardless of diagnosis, are summarized graphically in figure 6. They are as well correlated as Currie's (see table 2), but they

${ }^{66}$ Ackerknecht, op. cit., note 64 above, p. 104; Terence D. Murphy, 'Medical knowledge and statistical methods in early nineteenth-century France,' Med. Hist., 1981, 25: 301-19. 


\section{J. Worth Estes}

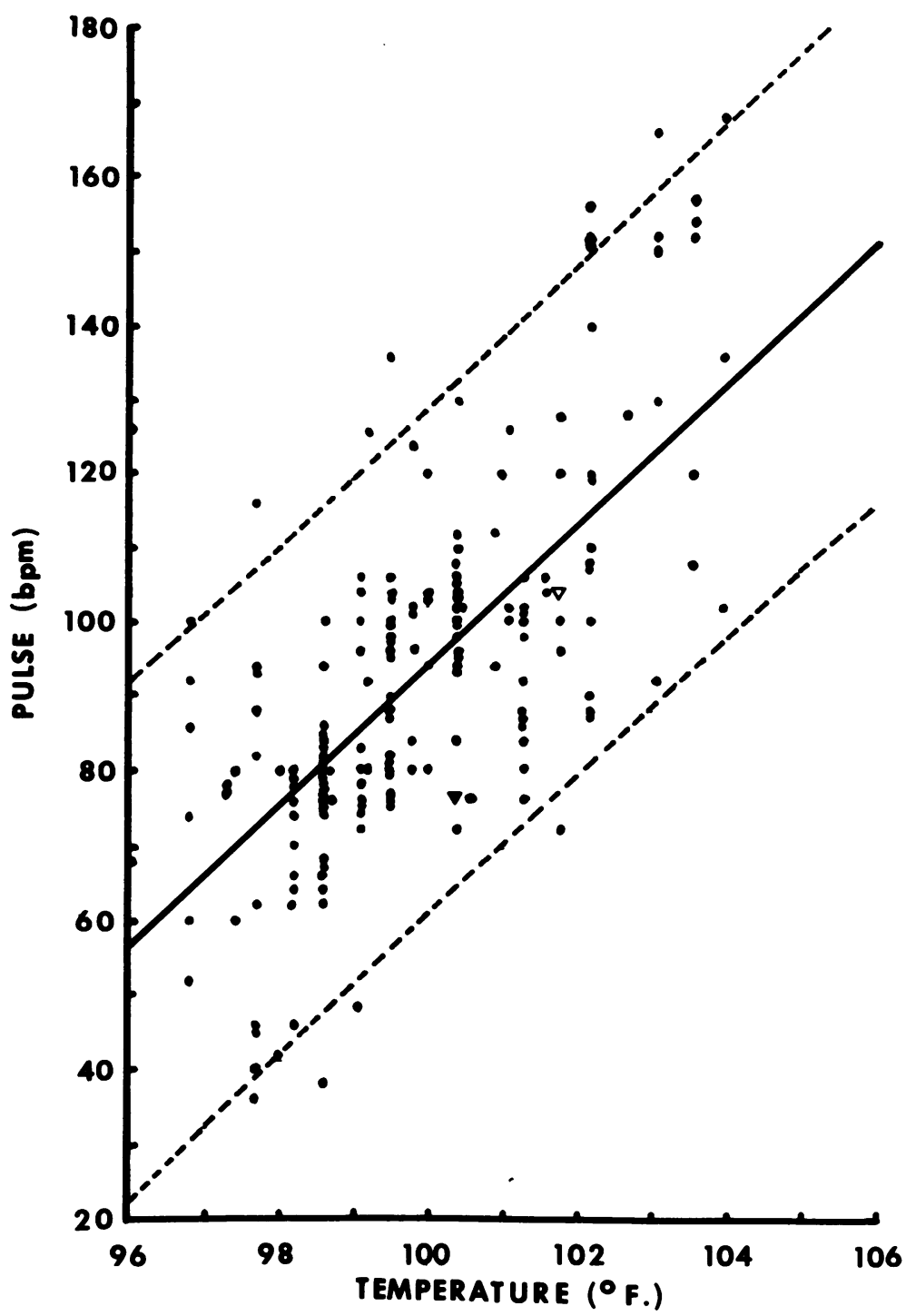

Figure 6. Computed line of best fit $(Y=9.34 X-840 ; N=178)$ and $95 \%$ Confidence Limits (dashed lines) relating pulse to thermometrically measured body temperature, compiled from data for 69 patients collected by Alfred Donné in the 1830s. Compiled from source cited in note 65 . Reproduced with permission from: J. Worth Estes, 'Patterns of drug usage in colonial America', in Robert I. Goler and Pascal James Imperato (eds.), Early American medicine: a symposium, New York, Fraunces Tavern Museum, 1987, p.30.

show that the pulse rose about nine beats per minute for each degree increment in temperature, three times the proportionality constant computed from Currie's observations.

Donné concluded that, while the temperature does not always follow the pulse in healthy persons, the two measurements are usually related in patients with diseases 
that affect either the nervous system or the oxygenation of blood (with the single exception of typhoid fever, in which he found a marked disproportion between the pulse and the temperature in his two patients with that diagnosis). Thus, Donné's findings supported the continued use of antiphlogistic remedies, such as "refrigerant" salts, as well as meat-free diets, Currie's cold water baths, and, especially, bloodletting.

The open triangle in figure 6 represents one of Donné's patients with "enteritis" before he was bled, while the closed triangle represents the same patient afterward. Clearly, bleeding had reduced his fever, as far as Donné could tell. Most eighteenthand nineteenth-century physicians would have agreed with Lyman Spalding of New York when he wrote, in 1817, that "The sheet anchor of our hope [in treating fever] is the lancet". He concluded that "so much blood [should be] drawn as will reduce the pulse to the standard of health"; $;$ most physicians probably removed from eight to twenty ounces of blood at each venesection. ${ }^{68}$ Twelve years earlier, James Currie had reported that he had watched the mercury level fall by twenty degrees in a thermometer he was holding in his fist while he was being relieved of eighteen ounces of blood when he had a temperature of $103^{\circ} .^{69}$

Because tachypnoea had long been observed to characterize many fever syndromes, Donné also measured the respiratory rate in about half of his fever patients; the data are summarized in figure 7 . His respiratory rate data were as strongly correlated with measured temperature as the pulse, and the man with "enteritis" showed the same antiphlogistic response to bleeding.

In 1666 John Locke had agreed with his contemporaries in ascribing the increased respiratory rate long known to be characteristic of fever to the physiological need "to prevent the lungs getting blocked and the right ventricle of the heart being overwhelmed by too great a flood of blood", and to "that irregular movement of the spirits, which in fever agitates the heart, causes more frequent vibrations of the diaphragm and lungs whence comes respiration". ${ }^{70}$ Over a century later, James Currie thought that febrile heat arose from increased intravascular friction. ${ }^{71}$ But other contemporary physicians, such as Lyman Spalding, when he wrote his Harvard medical dissertation in $1797,{ }^{72}$ would have agreed with Donné when he cited the discovery of the source of body heat by Lavoisier and LaPlace in $1780^{73}$ in explaining

${ }^{67}$ Lyman Spalding, Reflections on fever, and particularly on the inflammatory character of fever, New York, C. S. Van Winkle, 1817, pp. 38-9. On the other hand, John Huxham was surprised when bleeding resulted in a decreased pulse; Essay, note 38 above, p. 58.

${ }^{68}$ See, e.g., Risse, op. cit., note 32 above, p. 207, and Estes, 'Naval medicine', note 32 above, pp. $246-47$. However, although baroreceptor reflexes might be expected to increase the pulse in response to bleeding, I have found no data that unequivocally support the hypothesis. Indeed, no consistent pattern of pulse rate response to the removal of single units of blood can be ascertained in the data for 68 therapeutic phlebotomies summarized for me by Desiree Carlson, MD, of University Hospital, Boston. In a personal communication, one physician-patient has told me that he was surprised when he did not develop tachycardia during a massive internal haemorrhage.

${ }^{69}$ Currie, op. cit., note 25 above, vol. 2, p. 245.

${ }^{70}$ Kenneth Dewhurst, 'Locke's essay on respiration', Bull. Hist. Med., 1960, 34: 257-72, esp. p. 269.

71 Currie, op. cit., note 25 above, vol. 1, p. 249.

72 Lyman Spalding, An inaugural dissertation on the production of animal heat, Walpole, N.H., David Carlisle, Jun., 1797, pp. 8-10, 22-4.

${ }^{73} \mathrm{~A}$ useful abbreviated translation is in: Mordecai L. Gabriel and Seymour Fogel, Great experiments in biology, Englewood Cliffs, N.J., Prentice-Hall, 1955, pp. 85-93. 


\section{J. Worth Estes}

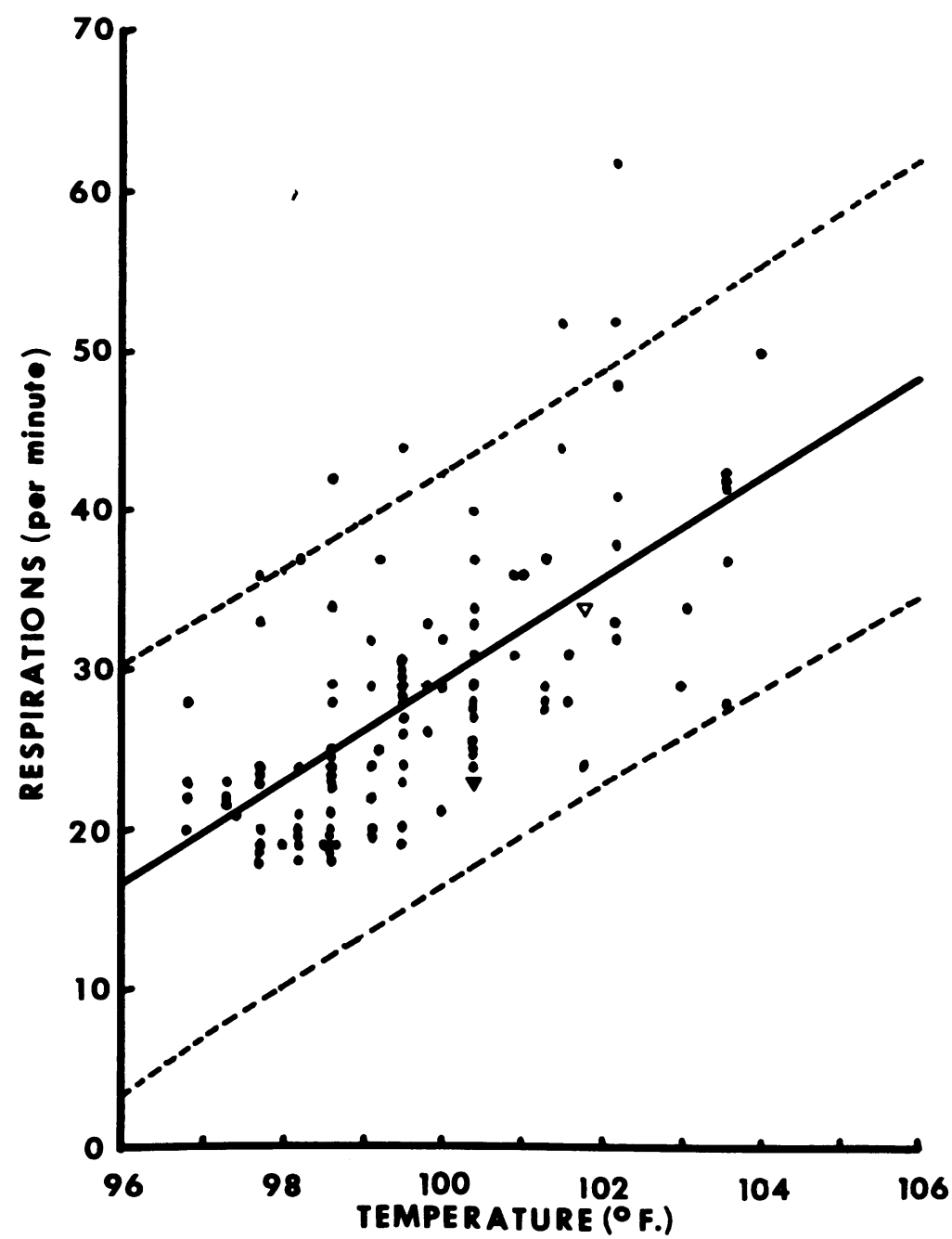

Figure 7. Computed line of best fit ( $\mathrm{Y}=3.15 \mathrm{X}-285 ; \mathrm{N}=112)$ and $95 \%$ Confidence Limits (dashed lines) relating respiratory rate to thermometrically measured body temperature, compiled from data for 38 patients collected by Alfred Donne in the 1830 s. Compiled from source cited in note 65 . Reproduced with permission from: J. Worth Estes, 'Patterns of drug usage', op. cit., figure 6 above, p. 31.

febrile tachypnoea. Donné noted that nine-tenths of the body's heat is produced by the chemical interaction of oxygen with the carbon contained in blood, resulting in the formation of carbonic acid (carbon dioxide). This permitted him to interpret rapid respirations as a manifestation of increased combustion, and, therefore, of increased heat production in the fevered body, because, he wrote, the respiratory rate increases in order to replace the oxygen consumed when it reacts with carbon.

Finally, Donné concluded that the pulse rate varies in direct proportion to the respiratory rate, as can be verified by his data summarized in figure 8 . He reasoned that the force of the circulation did not, all by itself, determine the temperature even in 
inflammatory diseases, and he noted that it was difficult to predict the exact pulse from temperature measurements. But, he added, his data did prove that pulse and respiratory rates rise and fall in parallel with body temperature, depending on the anatomical site of the febrile inflammation, thus confirming assumptions physicians had been making since antiquity.

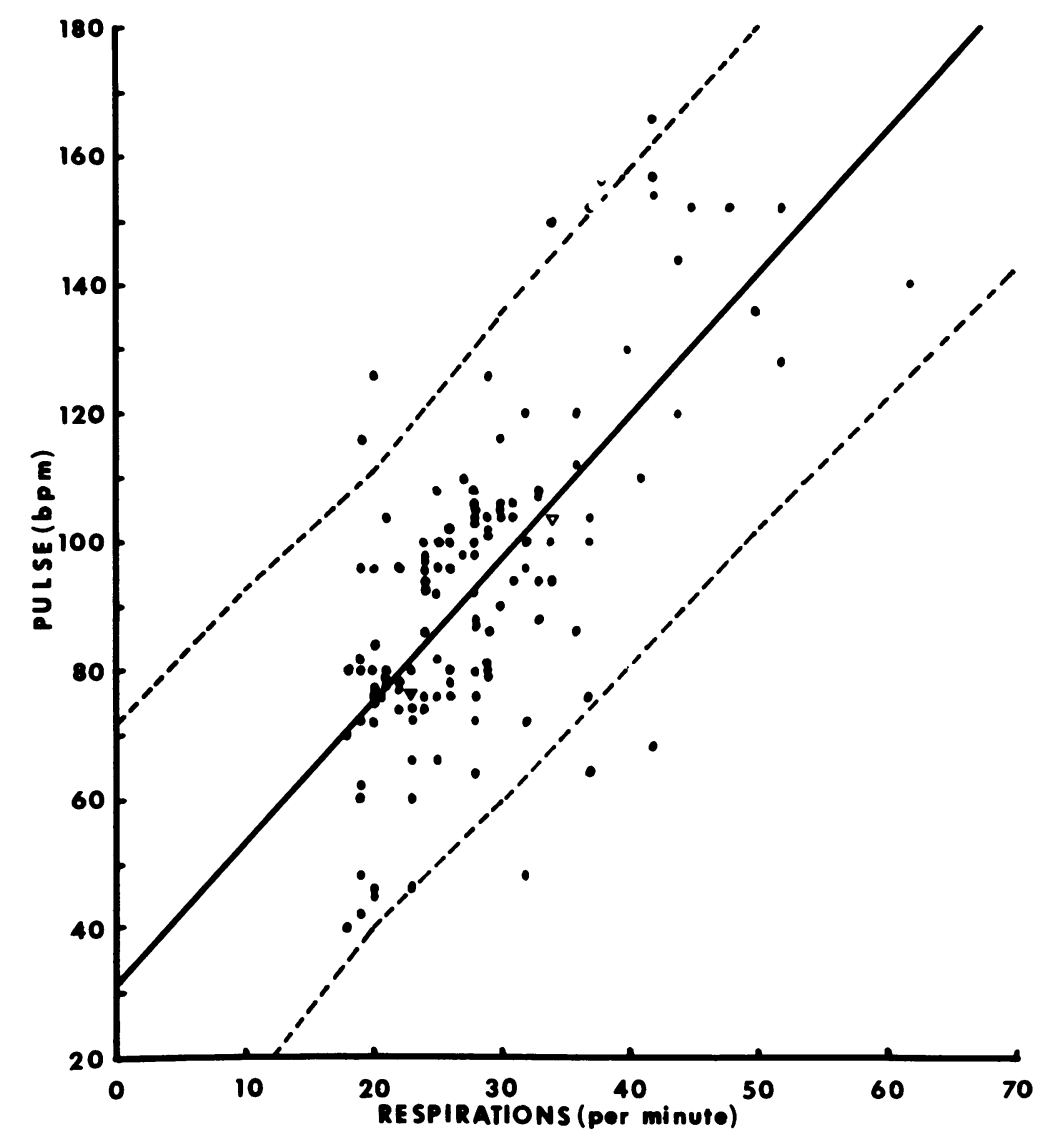

Figure 8. Computed line of best fit $(\mathrm{Y}=2.17 \mathrm{X}+32.2 ; \mathrm{N}=128)$ and $95 \%$ Confidence Limits (dashed lines) relating pulse rate to respiratory rate, from data for 34 patients collected by Alfred Donné in the 1830s. Compiled from source cited in note 65 .

THE SHORT CLINICAL THERMOMETER AND THE PULSE (1865-1875)

By 1864 William Aitken, professor of pathology at the British army medical school at Chatham, was popularizing the first truly self-registering clinical thermometers. They were sold in sets that included a straight instrument for oral use and a bent one for the axilla. Both were about eleven inches long, with scales etched directly on the glass. ${ }^{74}$

${ }^{74}$ John Burnett, 'The introduction of the clinical thermometer in Britain', unpublished MS kindly provided by Dr Burnett, of the Royal Museum of Scotland, Edinburgh; C. Keith Wilbur, Antique medical instruments, West Chester, Penn., Schiffer, 1987, p. 81. 


\section{J. Worth Estes}

When Carl Wunderlich of Württemberg (another pupil of Louis) ${ }^{75}$ wrote his 1868 book that is the real foundation of modern clinical thermometry, he cited both Currie and Donné, but he included none of their quantitative data. Wunderlich himself used a six-inch thermometer that was the forerunner of today's four-inch instrument. He did not attempt to relate pulse to measured temperature in his patients, but he did set out a "general rule for adults" in which he stated that pulse rates of 80 to 90 indicate slight febrile temperatures; those of 90 to 108 accompany moderate fevers; those of 108 to 120 "considerable fever"; and a faster pulse an even greater fever. He presented the data that are plotted in figure 9 (so that they can most conveniently be compared with those in figures 5 and 6), although they had originally been published in tabular form by Aitken in 1864 and Carl von Liebermeister in $1868 .^{76}$

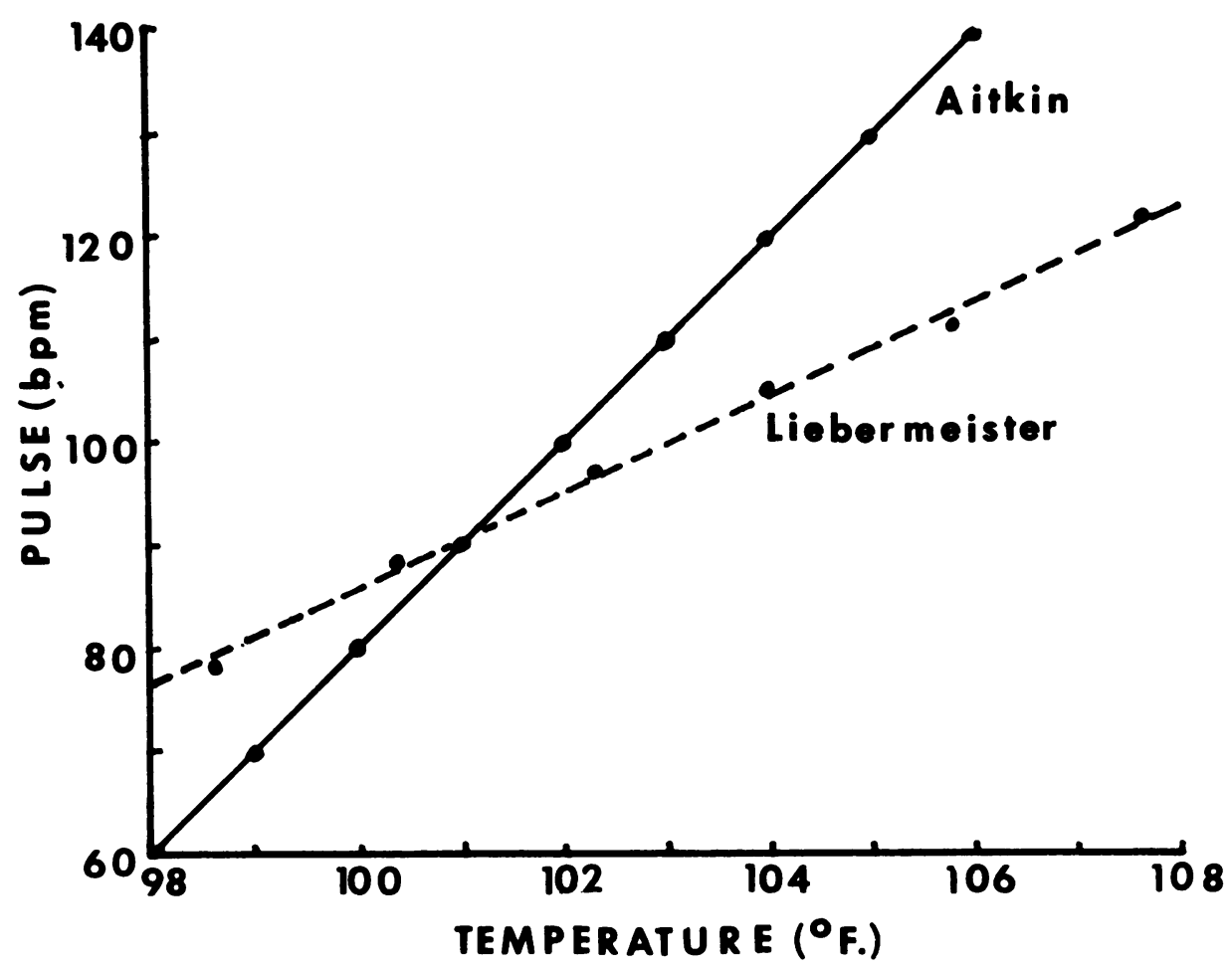

Figure 9. Computed lines of best fit relating pulse rate to thermometrically measured body temperature, from data collected by William Aitken $(Y=10 X-920)$ and Carl von Liebermeister $(Y=4.57 X-371.4)$ in the mid-nineteenth century. Compiled from source cited in note 76.

Explicitly agreeing with Aitken, Wunderlich concluded that, "As a general rule the co-relation of pulse and temperature may be stated as follows: namely, 'An increase of temperature of ONE DEGREE F. corresponds with an increase of TEN beats of the pulse per

${ }^{75}$ Ackerknecht, op. cit., note 64 above, p. 110.

${ }^{76} \mathrm{C}$. A. Wunderlich, On the temperature in diseases: a manual of medical thermometry, transl. W. Bathurst Woodman, London, New Sydenham Society, 1871, pp. 24-5, 28, 212-13. 


\section{Quantitative observations of fever}

minute", ${ }^{77}$ a value near that computed from Donne's data. The average increment which can be computed from Liebermeister's data (as reported by Wunderlich) is only 4.6 beats per degree rise in temperature, closer to the value computed from Currie's data. Although Wunderlich based his estimates on averaged (not on individual patients') data, he used the discrepancy to argue for the hypothesis that the varieties of fever can be differentiated by their respective chronological temperature patterns, as Donné and others had postulated, although the principle was confirmed only by Wunderlich's observations. ${ }^{78}$

Table 2 summarizes virtually all the quantitative attempts to relate pulse or respiratory rate to concomittantly measured temperature that had been made before Wunderlich finished his book. The slopes of the computed pulse-on-temperature curves range from as low as three to as high as ten beats per minute per degree rise in temperature, even if all the correlation coefficients are highly significant.

Table 2. Statistical relationships of pulse and respiratory rate to thermometrically measured body temperature computed from data collected before 1870; see figures 5-7 and 9.

\begin{tabular}{|c|c|c|c|c|}
\hline $\begin{array}{l}\text { Pulse }(\mathrm{Y}) \text { on } \\
\text { Temperature }(\mathrm{X}) \\
\text { [Currie, 1805] }\end{array}$ & $\begin{array}{l}\mathrm{r}^{*} \\
0.614\end{array}$ & $3.3 \mathrm{bpm} /{ }^{\circ} \mathrm{F}$. & Precision & $\begin{array}{l}\text { Information } \\
\text { Yield }\left(\times 10^{4}\right)\end{array}$ \\
\hline $\begin{array}{l}\text { Pulse }(\mathrm{Y}) \text { on } \\
\text { Temperature }(\mathrm{X}) \\
\text { [Donné, 1835] }\end{array}$ & 0.673 & $9.3 \mathrm{bpm} /{ }^{\circ} \mathrm{F}$ & 36.7 & 7.4 \\
\hline $\begin{array}{l}\text { Respiratory rate }(\mathrm{Y}) \text { on } \\
\text { Temperature }(\mathrm{X}) \\
\text { [Donné, 1835] }\end{array}$ & 0.646 & $3.2 / \mathrm{min} /{ }^{\circ} \mathrm{F}$ & 13.7 & 53.4 \\
\hline $\begin{array}{l}\text { Pulse }(\mathrm{Y}) \text { on } \\
\text { Temperature }(\mathrm{X}) \\
\text { [Aitken, 1864] }\end{array}$ & - & $10.0 \mathrm{bpm} /{ }^{\circ} \mathrm{F}$ & - & $\longrightarrow$ \\
\hline $\begin{array}{l}\text { Pulse }(\mathrm{Y}) \text { on } \\
\text { Temperature }(\mathrm{X}) \\
\text { [Liebermeister, 1868] }\end{array}$ & - & $4.6 \mathrm{bpm} /{ }^{\circ} \mathrm{F}$ & - & - \\
\hline
\end{tabular}

${ }^{*} \mathrm{r}=$ Pearson product-moment correlation coefficients; all are statistically significant at $\mathrm{p}<0.01$. See text for interpretation of indices of Precision and Information Yield.

The lowest numerical values under "precision" in table 2 indicate the highest degree of predictability. ${ }^{79}$ Thus, Donné's pulse data can now be seen to have predicted temperature more accurately than Currie's data could, while Donnés respiratory rates were even "better" as correlates of temperature. Those conclusions, as well as the indices of "information yield" (the larger numbers are associated with those

${ }^{77}$ Ibid., p. 213.

${ }^{78}$ Lloyd G. Stevenson, 'Exemplary disease: the typhoid pattern', J. Hist. Med., 1982, 37: 159-81.

${ }^{79}$ For the indices of precision and information yield, see J. Worth Estes, 'Application of the kinetics of heparin to the formulation of dosage schedules', in R. A. Bradshaw and S. Wessler (eds.), Heparin, New York, Plenum, 1975, pp. 181-2, and Estes, 'Kinetics of the anticoagulant effect of heparin', J. Am. med. Ass., 1970, 212: 1492-5. 


\section{J. Worth Estes}

"experiments" that produced the greater amount of predictive information), help validate the greater reliance placed by some physicians on respiratory rate than on pulse rate as a clinical guide to fever during the years before clinical thermometry became routine.

Édouard Séguin, who helped popularize the thermometer in the United States, was not very impressed with the utility of the respiratory rate for assessing fever patients. He noted, in 1867, "That in the majority of cases a rise of temperature is contemporary with a rise of pulse, but that, on the other hand, there appears generally to be but little connection between temperature and frequency of respirations." ${ }^{80}$ Still, when all three measures were taken together, they did help physicians evaluate their febrile patients.

\section{EPILOGUE (1875-1899) AND CONCLUSIONS}

Although the Hippocratic writings do not mention the peripheral pulse as a diagnostic aid, it had entered medical texts by about 300 BC. ${ }^{81}$ Like their professional ancestors in ancient Greece, sixteenth-century physicians still used touch as their principal criterion for evaluating body heat, ${ }^{82}$ but by 1708 Georg Ernst Stahl was recommending that approximately equal diagnostic weight be given both to "feelings" of heat and to a "uniform change in the movement of the blood" ${ }^{83}$ while Willis had already adopted the latter yardstick. The gradually increasing emphasis placed on pulse-counting by the most widely read theorists (save Cullen) might, then, have been expected to have engendered more experimental study of the relationship between it and readings made on Fahrenheit's new thermometer, but such studies were slow to appear. Even Laennec did not report measured pulse or respiratory rates in his detailed studies of pulmonary disease ${ }^{84}$ The few experimental studies, or even simple collations of numerical observations, reported before the mid-nineteenth century were sporadic and produced little change in physicians' clinical thinking.

As Bates has pointed out. "Fevers were the very essence of a medical, not a scientific subject" in the seventeenth century. That is, as he also noted, fever was not readily amenable to experimentation in man or animals, ${ }^{85}$ although a few such attempts (e.g., those of Hales and Hunter) were made during the ensuing century. Today's usual scientific procedure is to collect facts, analyse them, and develop a theory derived from them, but eighteenth-century physicians "tended to use facts chiefly to justify their a priori systems". ${ }^{86}$ In 1785 Lavoisier acknowledged that fallacy in his observation that,

${ }^{80}$ Édouard Séguin, 'Clinical thermometry', Med. Rec., 1867, 1: 516-19.

${ }^{81}$ G. E. R. Lloyd (ed.), Hippocratic writings, Harmondsworth, Middlesex, Penguin Books, 1978, pp. 31, 348,350 .

${ }^{82}$ Iain M. Lonie, 'Fever pathology in the sixteenth century: tradition and innovation', in Bynum and Nutton (eds.), op. cit., note 5 above, pp. 19-44.

${ }_{83}$ Johanna Geyer-Kordesch, 'Fevers and other fundamentals: Dutch and German medical explanations c. 1680 to 1730 ', in ibid., pp. $99-120$.

${ }_{84}$ Mitchell, op. cit., note 6 above, pp. 22-3.

85 Don G. Bates, 'Thomas Willis and the fevers literature of the seventeenth century', in Bynum and Nutton (eds.), op. cit., note 5 above, pp. 45-70.

${ }_{86}$ James H. Cassedy, American medicine and statistical thinking, 1800-1860, Cambridge, Mass., Harvard University Press, 1984, p. 55; also see Risse, op. cit., note 32 above, p. 284, and Murphy, op. cit., note 66 above, p. 315. 


\section{Quantitative observations of fever}

"The human mind gets creased into a way of seeing things." ${ }^{, 87}$ Indeed, physicians of his time, such as James Gregory and Andrew Duncan at Edinburgh, were, like their patients, far more interested in effective therapies than in scientific investigation of the phenomena of fever. ${ }^{88}$

Before the mid-nineteenth century, pulse and respiratory rates were the only quantitative data (other than age and duration of illness) that were noted on patient records at Boston's Massachusetts General Hospital, and then for only a minority of patients. But, by the 1880 s, daily pulse, temperature, and respiration measurements were being entered on printed graphs prepared especially for that purpose. ${ }^{89}$ The impetus for such systematic recording of vital signs had probably arisen in the newly emerging definitions that, for the first time, permitted differentiating the many syndromes that had previously been lumped together as generic "fever". Before those differentiations were made, fever could only be regarded a having "an underlying unity", 90 based on long-accepted theories that precluded detailed, much less numerical, study of its clinical phenomena. The simple fact that temperature patterns can vary among the various fever syndromes, not widely recognized before Wunderlich's book appeared, surely accounts for the Edinburgh physicians' inability to correlate their patients' symptoms with their measured temperatures. Thus, as long as clinical thermometers were thought incapable of providing useful information, there was little incentive to use them.

In 1865 Claude Bernard asserted that "doubt is the foundation of experimentation".91 Because there was little doubt of the validity of accepted theories of the mechanisms of fever before about 1870 , there was little stimulus to collect numerical observations, or to devise experiments, that would-or could-test those theories. Thus, the data published by Alfred Donné in 1835 would have been seen by his contemporaries merely as confirming their time-tested theories of the essential unity of fevers. Only some years later would two important typical fevers, typhoid and typhus, be differentiated-but chiefly on clinical and pathological grounds, ${ }^{92}$ not on the temperature patterns that Wunderlich added to their definitions.

Eventually, quantitative assessments of patients' responses to their medicines would permit the emergence of information that effectively dissipated physicians' longstanding frustrations with the therapeutic failures they often witnessed despite the face validity of the disease theories they had learned. In the meantime, new anatomical and physiological discoveries did permit them to abandon some ancient assumptions about the mechanisms of action of the drugs they prescribed. For instance, as early as the 1840s physicians could stop arguing whether digitalis stimulated or depressed the

\footnotetext{
${ }^{87}$ Quoted in Bernard Barber, 'Resistance by scientists to scientific discovery', Science, 1961, 134: 596-602.

${ }^{88}$ Smith, 'Medical science', note 5 above.

89 John Harley Warner, The therapeutic perspective: medical practice, knowledge, and identity in America, 1820-1885, Cambridge, Mass., Harvard University Press, 1986, pp. 154-5.

${ }^{90}$ Leonard G. Wilson, 'Fevers and science in early nineteenth century medicine', J. Hist. Med., 1978, 33: $386-407$.

${ }^{91}$ Claude Bernard, An introduction to the study of experimental medicine, transl. Henry Copley Green, New York, Dover, 1957, pp. 203.

92 Stevenson, op. cit., note 78 above; Wilson, op. cit., note 90 above.
} 


\section{J. Worth Estes}

vascular system in patients with dropsy: as long as it had been regarded as a fever, the reduction in pulse rate produced by the drug was adduced as evidence for both conclusions. ${ }^{93}$

However, therapeutic change would not be based on scientific data alone. For instance, by the middle of the nineteenth century, purported tonics and stimulants, such as quinine, iron, and alcohol, came to dominate American therapies as physicians adopted the popular assumption that the steadily increasing standard of living made possible by industrialization and urbanization was undermining Americans' collective health by allowing living conditions to become softer than they had been (despite the increasing morbidity and mortality in crowded urban tenements). ${ }^{94}$ Even Édouard Séguin's advocacy of thermometry was based, in part at least, on his opinion that it could permit families to make objective observations that would, in turn, counteract their dependence on medical quackery. ${ }^{95}$

In the 1890s, William Osler plotted twice-daily measurements of temperature, pulse, and respiratory rate on the same graph to show that they rise and then fall together in one common fever syndrome, lobar pneumonia. ${ }^{96} \mathrm{He}$ intended his graph, perhaps modelled on one designed by Séguin and his son Edward, ${ }^{97}$ to exemplify the healing power of nature which had been fully appreciated by James Gregory and Andrew Duncan a century earlier. The vis medicatrix naturae had been, indeed, integral to medical practice for many centuries before Jacob Bigelow began to enhance professional awareness of its potential benefits in $1835 .^{98}$

Osler also reiterated Alfred Donné's theme that each diagnostic fever category has its own thermometric pattern (although Osler was following Wunderlich, not Donné). But then Osler went on to recommend some of the same therapies ${ }^{99}$ that Stephen Hales had studied and that James Gregory, Andrew Duncan, and James Currie had prescribed, including quinine, cold water, and bleeding in the first day or two of the disease, even if leading authorities had for some time been deploring antiphlogistic and stimulant drugs as "neither rational nor scientific". 100

Not until near the end of the nineteenth century did quantitative study of the signs of fever provide physicians with much specifically therapeutic guidance, although that

93 Estes, op. cit., note 5 above, pp. 172-82, 189-96.

94 Warner, op. cit., note 89 above, pp. 68,98 ; J. Worth Estes, 'The pharmacology of nineteenth-century patent medicines', Pharmacy in History, 1988, 30: 3-18.

95 Daniel M. Musher, Edward A. Dominguez, and Ariel Bar-Sela, 'Édouard Séguin and the social power of thermometry', New Engl. J. Med., 1987, 316: 115-17.

96 William Osler, The principles and practice of medicine, 3rd ed., New York, D. Appleton, 1898, p. 116. The same graph had appeared in the first (1892) edition but with a less extensive discussion.

${ }^{97}$ Musher et al., op. cit., note 95 above.

98 Wilson, op. cit., note 90 above; Gregory, in 'Febras continua', op. cit., note 29 above; J. Worth Estes, 'Therapeutic practice in colonial New England', in Philip Cash, Eric H. Christianson, and J. Worth Estes (eds.), Medicine in colonial Massachusetts, 1620-1820, Boston, Colonial Society of Massachusetts, 1980, pp. 289-383, esp. p. 348; Estes, The medical skills of ancient Egypt, Canton, Mass., Science History Publications, 1989 , pp. 106, 112, 118, 123, 183-4.

99 Osler, op. cit., note 96 above, pp. 134-7. Many physicians agreed with Osler; see, e.g., texts like William Tully's Materia medica or pharmacology and therapeutics, 2 vols., Springfield, Jefferson Church, MD, 1857, vol. 1, pp. 442-3, 455-65; or accounts such as that in J. Worth Estes and David M. Goodman, The changing humors of Portsmouth: the medical biography of an American town, 1623-1983, Boston, Countway Library of Medicine and Science History Publications, 1986, p. 106.

100 Warner, op. cit., note 89 above, p. 268. 


\section{Quantitative observations of fever}

was what they wanted most. ${ }^{101}$ Not only had Pierre Louis' now-famous numerical assessment of bleeding in the treatment of the febrile illness he called "pneumonitis" failed to hasten physicians' abandonment of that antiphlogistic method, his 1828 work on the subject had actually encouraged its use at the Massachusetts General Hospital. ${ }^{102}$ Thus, it is not very surprising that quantitative studies of the pulse and temperature were seldom undertaken (or at least seldom published) so long as they seemed unable to result in more dependable therapy. In the eighteenth century, several physicians (e.g., John Millar and John Haygarth) used the quantitative approach of vital statistics, but not thermometers, in their studies of fever. ${ }^{103}$ In the 1860 s, Liebermeister and others (e.g., Ernst Brand of Stettin, and Theodor Jürgenson of Kiel) did use thermometers to help evaluate the efficacy of cold water in the treatment of typhoid fever, and in the 1880s and 1890s other investigators (e.g., Wilhelm Filehne, the pharmacologist at Erlangen) used them to assess antipyretic drugs such as antipyrine, but all these nineteenth-century investigators relied even more heavily on simple recovery rates than on thermometers when making therapeutic judgements. ${ }^{104}$

Thus, in the aggregate, Hales's novel animal experiments, therapeutic trials monitored by pulse counting (like those of Gregory and Duncan), and Donne's measurements of pulse, respiration, and temperature, simply reinforced physicians' protopharmacological understanding of fever over the 165 years after Hales's book appeared; not even the discovery of bacteria added much more. ${ }^{105}$ Instead, by 1898 most of the clinically important advances in the study of fevers had come from careful correlations of observed symptoms with specific organ pathology. (By contrast, from 1857, when Karl Vierordt published the first red blood cell counts, numerical data played increasingly important roles in defining haematological diseases and treatments for some of them.) ${ }^{106}$ The organisms that caused many infectious diseases had been identified by the $1890 \mathrm{~s}$, but only some of the antiphlogistic and tonic treatments available in the 1790 s had disappeared from common usage by then. ${ }^{107}$

Physicians of the eighteenth and nineteenth centuries could feel comfortable with their theories and their medicines, since they knew that about 95 per cent of their adult patients survived the fevers for which they were treated, ${ }^{108}$ at least in the absence of epidemics of devastating diseases such as smallpox. The body's ability to heal itself was probably responsible for more of those historical cures than the placebo effect, although the latter is now known to relieve about one third of patients with many of the

${ }^{101}$ Smith, 'Medical science', note 5 above.

102 J. Worth Estes, 'Making therapeutic decisions with protopharmacologic evidence', Trans. \& Stud. Coll. Phys. Phila., 1979, 1: 116-37.

${ }_{103}$ Ulrich Tröhler, "“To improve the evidence of medicine": arithmetic observation in clinical medicine in the eighteenth and early nineteenth centuries,' Hist. Phil. life Sci., 1988, 10, suppl.: 31-40.

104 Jan R. McTavish, 'Antipyretic treatment and typhoid fever: 1860-1900', J. Hist. Med., 1987, 42: 486-506.

${ }^{105}$ Warner, op. cit., note 89 above, pp. 271-3, 279.

${ }^{106}$ Maxwell M. Wintrobe, Hematology, the blossoming of a science, Philadelphia, Lea \& Febiger, 1985, pp. 51-2.

${ }_{107}$ J. Worth Estes, Dictionary of protopharmacology: therapeutic practices 1700-1850, Canton, Mass., Science History Publications, 1990, pp. v-vi.

${ }^{108}$ Estes, op. cit., note 5 above, pp. 70-1, 100-3; idem, 'Naval medicine', note 32 above; idem, 'Therapeutic practice', note 98 above, pp. 300,352 . 


\section{J. Worth Estes}

symptoms, including pain, cough, and headache, that may accompany febrile illnesses. ${ }^{109}$

The therapeutic rationales used by the physicians at the Edinburgh Infirmary who measured their patients' pulses each day typified the individualized approach to therapeutics commonly used before the concept of untreated negative control patients became essential for evaluating new drugs. When that idea finally flowered, it would become obvious that efficacy could not be established simply by assessing a given patient's symptoms, or by measuring his vital signs. Instead, proof of efficacy would have to rely on comparing groups of treated and untreated patients. Thus, the introduction of negative controls into such comparisons required that physicians abandon the notion that each patient was absolutely unique. That change in therapeutic thinking may have been facilitated by earlier pathological studies that had already demonstrated the utility of making clinical predictions based on carefully grouped observations. The basic idea of negative controls had entered many experimental sciences, including biology, by the 1870s; Hales's use of them was a very early one, but they had been employed in studies of physical phenomena at least 85 years earlier. Nevertheless, such controls did not become widely recognized as critical to the appropriate evaluation of medical therapeutic agents until the 1940 s. $^{110}$

Furthermore, not even the quantitative statistical methods developed by Francis Galton and Karl Pearson between 1886 and $1911^{111}$ could hasten the emergence of definitive fever therapies (even if the idea of negative controls was certainly implicit in Pearson's description, in 1899, of the chi-squared test, which is still used for comparing treated and untreated patients). Although the advent of true antipyretics, culminating in the introduction of aspirin in the last year of the nineteenth century, ${ }^{112}$ did help physicians to focus their attention on thermometry, ${ }^{113}$ they would have to wait until the 1930s, two hundred years after Hales's pioneering "pharmacological" experiments, before the first truly selective anti-infective-and, therefore, truly antifebrile-antipyretic drugs would appear, in the form of the antimicrobial sulphonamides.

\footnotetext{
${ }^{109}$ Henry K. Beecher, 'Quantitative effects of drugs on the mind', in Paul Talalay (ed.), Drugs in our society, Baltimore, Johns Hopkins Press, 1964, pp. 77-89, esp. pp. 82-3.

110 Louis Lasagna, 'On evaluating drug therapy: the nature of the evidence', in ibid., pp. 91-105; Edwin G. Boring, 'The nature and history of experimental control', Am. J. Psychol., 1954, 67: 573-89. The idea of the "double-blind" clinical trial was probably conceived no earlier than 1937; it was named in 1950, according to a 27 June 1970 letter from Harry Gold to Bo Holmstedt published in Pharmacologist, 1989, 31: 235. The first single-blind trial may be one published by John Haygarth of Chester in 1800; Tröhler, op. cit., note 103 above, pp. $35-6$.

111 Boring, op. cit., note 110 above. For the development of quantitative statistical methods see: Helen M. Walker, Studies in the history of statistical method, Baltimore, Williams \& Wilkins, 1931; and Stephen M. Stigler, The history of statistics: the measurement of uncertainty before 1900, Cambridge, Mass., Belknap Press of Harvard University Press, 1986. Also see Murphy, op. cit., note 66 above.

112 McTavish, op. cit., note 104 above.

113 Warner, op. cit., note 89 above, pp. 157-8.
} 